\title{
Quantitative estimation of essential/toxic elemental levels in the serum of esophagus cancer patients in relation to controls
}

Muhammad Abdul Qayyum ( $\sim$ qayyumkh21@yahoo.com)

University of Education https://orcid.org/0000-0001-6910-1609

Muhammad Habib Sultan

Government College University Faisalabad

Zahid Farooq

University of Education

Khawaja Muddassir

University of Tennessee College of Medicine: The University of Tennessee Health Science Center College of Medicine

Tahir Farooq

Government College University Faisalabad

Ahmad Irfan

King Khalid University

\section{Research Article}

Keywords: Esophagus cancer, Serum , Essential/toxic element, AAS, Statistical analysis

Posted Date: February 15th, 2022

DOI: https://doi.org/10.21203/rs.3.rs-1242874/v1

License: () (7) This work is licensed under a Creative Commons Attribution 4.0 International License. Read Full License

Version of Record: A version of this preprint was published at Environmental Science and Pollution Research on June 28th, 2022. See the published version at https://doi.org/10.1007/s11356-022-21651-7. 


\section{Abstract}

Esophageal cancer is a very deadly disease ranking 8th most common cancer in terms of incidence and the 6th highest in terms of mortality both in USA and around the world. A growing body of evidence indicated that changes in the concentrations of essential and toxic elements may affect/increase esophagus carcinoma risk. The aim of this study was to measure serum levels of essential and toxic ( $\mathrm{Fe}, \mathrm{Na}, \mathrm{Ca}, \mathrm{K}, \mathrm{Zn}, \mathrm{Mg}, \mathrm{Co}, \mathrm{Se}, \mathrm{Cu}, \mathrm{Ni}, \mathrm{Mn}, \mathrm{Sr}, \mathrm{Pb}, \mathrm{Li}, \mathrm{Sb}, \mathrm{Cr}, \mathrm{Ag}, \mathrm{Cd}, \mathrm{As}$ and $\mathrm{Hg}$ ) elements in patients with esophagus carcinoma and controls. Atomic absorption spectroscopy was used to determine serum concentrations of essential and toxic elements by using nitric acid/perchloric acid-based wet digestion method. Mean levels of $\mathrm{Cu}, \mathrm{Ni}, \mathrm{Cr}, \mathrm{Cd}, \mathrm{Pb}, \mathrm{As}$ and $\mathrm{Ag}$ were exhibited to be significantly higher and mean Se, Co, Zn, Ca, Fe, Hg, Li and Mg were noted lower in the serum of cancer patients than controls. The correlation coefficients among the elements in the cancerous patients revealed significantly dissimilar communal relationships than the controls. Further, multivariate methods demonstrated considerably different apportionment between the elements in the cancerous patients and the controls. Significant inequalities in the elemental concentrations were also observed for esophagus cancer types (adenocarcinoma and squamous cell carcinoma) and stages (I, II, III, and IV) between the patients. Majority of the elements exposed perceptible disparities in their levels based on smoking habits, dietary habits, habitat and gender of the esophagus cancer patients and controls. Multivariate analysis of the essential and toxic elemental data explained significantly divergent apportionment in the serum of esophagus cancer patients when compared to controls.

\section{Introduction}

The heavy metals pollution is augmenting and the amassing of these toxins in human body posed lethal effects inducing various kinds of complex diseases such as cancer (Ren et al. 2021). Esophagus cancer (EC) is one of the destructive digestive malignant ranking 8th most common cancer in terms of incidence and the 6th highest in terms of mortality both in USA and around the world (Bray et al. 2018). It is one of the malignancies with highest geographic, ethnic, and gender variations (Huang et al. 2021). In addition, its incidence rate is elevated in men than women and is aggressive in nature along with poor prognosis (Lin et al. 2017). Esophagus malignancy develops from the epithelium of the esophagus possessing two major histological types known as esophagus squamous cell carcinoma (ESCC) and esophagus adenocarcinoma (EAC) based on latest version of the UICC/AJCC TNM classification (8th edition) (Rice et al. 2017). ESCC arises from the middle or upper third of the esophagus, whereas EAC develops from the distal third of esophagogastric junction (Jain and Dhingra 2017). The progression and therapeutic strategy for EC in patients is determined via stage at the time of diagnosis (Wang et al. 2018). Further, knowing the exact stage of the tumor is fundamental in order to make the right decision about the treatment. Despite advancement in diagnostic and therapeutic/surgical approaches, most of the EC patients were diagnosed at an advanced stage with a poor prognosis, causing high mortality (Xie et al. 2019). As with most carcinomas, the exact cause of EC is not yet known. However experts believe that use of tobacco, alcohol consumption, betel quid chewing, gastroesophageal reflux disease, family history, obesity, eating processed meat, physical inactivity, plummer-vinson syndrome, tylosis, low intake of fresh fruits/vegetables and exposure to ionization radiation as well as exposure to metals can increase the risk of EC (Ren et al. 2021; Huang et al. 2021; Xie et al. 2019; Yang et al. 2021). A growing body of evidence has showed that there is a link among exposure to metals and EC and the evidence is sufficient to infer a causal relationship between these two variables (Lin et al. 2017; Xie et al. 2019; Dar et al. 2008). Further, hot beverage drinking, poor oral hygiene and low income masses possessed a higher risk of mortality from EC because patients have less access to prevention and treatment services especially in developing countries like Pakistan (Asghar et al. 2021). It has been well known that the trace elements have a great influence in the body on cellular structure stability, the stability of nucleic acids and immunity (Abnet et al. 2018). Studies suggest deficiency/excess of trace elements could severely impair hosts' resistance against carcinogenic stress and play an important role in tumor incidence as well as progression (Joshaghani et al. 2017; Lin et al. 2017). Based on epidemiological and clinical studies on the role of trace metals and carcinoma in humans, it is logical to assume that trace elements influence EC development (Yang et al. 2021).

Quantification of essential and toxic elements in the biological fluids is currently used as diagnostic tool for a number of diseases including cancer and for the assessment of nutritional as well as metabolic status (Mahmood et al. 2021; Lin et al. 2017). Accordingly, various clinical and epidemiological studies have investigated the associations among elemental exposures and EC risk (Xie et al. 2019; Joshaghani et al. 2017). In blood, serum, hair, saliva, nails and urine, these elements are stored and have been therefore used as indicators for the quantification of elements in the subjects (Sohrabi et al. 2021; Kazi et al. 2015). Nevertheless, the choice of the appropriate specimen/sample depends on number of factors; toxicokinetics, the convenience/invasiveness of the specimen collection procedure, and the potential for specimen contamination (Mahmood et al. 2021). For instance serum is the most common specimens used as biomarkers of internal dose to diagnose deficiency or exposure to toxic metals (Qayyum et al. 2020). Serum is the most suitable and reliable biomarker for biomonitoring of elements as it come in contact to every part of the body in the form of blood and reflect the current body burden of the trace metals (Qayyum et al. 2020). Studies on the relationship between elemental exposure and carcinoma of esophagus in Asian population especially in Pakistan remain scarce. Since, no publications on the comparative evaluation of elemental concentrations in the serum of EC and non-cancerous in Pakistani subjects could be found. In this context, the current study was undertaken to estimate the concentrations of 20 essential and toxic elements ( $\mathrm{Fe}, \mathrm{Ca}, \mathrm{Na}, \mathrm{K}, \mathrm{Mg}, \mathrm{Zn}, \mathrm{Co}, \mathrm{Sr}, \mathrm{Pb}, \mathrm{Li}, \mathrm{Se}, \mathrm{Sb}$, $\mathrm{Cu}, \mathrm{Mn}, \mathrm{Ni}, \mathrm{Cr}, \mathrm{Ag}, \mathrm{Cd}, \mathrm{As}$ and $\mathrm{Hg}$ ) in the serum of esophagus carcinoma patients and controls. In addition, elemental levels in serum of EAC and ESCC patients and various stages of EC patients were also investigated. Moreover, the differences in element levels in subjects' gender, habitat, smoking and dietary habits were analyzed, which could not be found in the previous studies. Eventually, via statistical treatment and multivariate analysis, a possible connection could be suggested among the elemental variations and the occurrence of EC. The results derived from the present biomonitoring investigation would be used as a primary tool to get information to plan preventive approaches and yielding better diagnostic accuracies.

\section{Materials And Methods Study population}


A total of 378 esophagus carcinoma patients (newly diagnosed) and 353 matching healthy participants (controls) were recruited in 2018-2019 from Allied Hospital (Faisalabad Medical University) Faisalabad Pakistan. Prior starting the study, it was approved by the Ethics Committee of hospital (Ref. No. UEFC/2019/R0485) on human experimentation and with the revised Helsinki Declaration. In patients, the diagnosis was confirmed based on clinical, radiological and histopathological (biopsy) features. The selected participants were newly diagnosed carcinoma of esophagus and were recruited on volunteer basis because these patients were visited to the hospital for their regular checkup. Further their treatment/medication was not started (radiotherapy, chemotherapy and surgery). The type and stage of EC patient was noted from the personal file saved in the hospital record. More than $60 \%$ of condition of patients was apparently worse in terms of chronic illnesses, poverty, malnutrition, and ignorance of ailment for longer time. The study donors were not using any kind of mineral or vitamin supplements from the couple of months as well. All the study participants were aware of the purpose of the current work and signed the informed consent prior the sample collection. Patients with EC with different ages, gender, occupation, height, weight, history, nutritional habits, smoking behaviors, drinking water preferences, adobe, medication and medical histories were noted via questionnaire was obtained from all study participants prior to the collection of the blood samples. The healthy donors were also matched with the EC patients regarding age, demographics, residence, gender, dietary and smoking habits. Mostly, the healthy donors had close relationship with the EC patients; thus, they possessed similar socioeconomic status and environmental exposure. Moreover, BMI value was calculated by dividing weight in kilograms $(\mathrm{kg})$ by height in squared meters ( $\mathrm{m})^{2}$ of each participant at the time of diagnosis (Qayyum et al. 2020).

\section{Sample collection and processing}

All subjects were requested to fast for six hours before blood sample collection. For collection of blood sample, about ten milliliter of venous blood sample was drawn from antecubital vein through venipuncture method. Firstly, $70 \%$ isopropyl alcohol was used to clean the skin of each participant. The blood sample was stored in specially designed evacuated tubes. Proper precautionary measures were adopted so as to avoid any kind of external contamination. Five milliliter of blood sample was send to the pathological laboratory of the hospital for biochemical analysis using standard methods. While the remaining $5 \mathrm{~mL}$ of blood sample was used for separating the sera. At room temperature, the blood was clotted after 30 min. The blood was centrifuged for $10 \mathrm{~min}$ at $3000 \mathrm{rpm}$ in the centrifuge machine after the blood has clotted completely. The supernatant fluid (serum) was separated with the help of pipette (Appendorf, 105893Z), labeled and stored at $-15^{\circ} \mathrm{C}$. For digestion, serum sample was correctly weighted by the analytical balance of each participant. Duplicate serum samples of EC patients and healthy donors were directly taken into pyrex flasks separately. Added 10 milliliter of concentrated $\mathrm{HNO}_{3}$ to each flask and remained for $10 \mathrm{~min}$, then the flasks were covered with watch glasses and placed on the hot plate. The temperature of hot plate was gradually increased and finally maintained at $60^{\circ} \mathrm{C}$ for $30 \mathrm{~min}$. The pyrex flasks were put off from the hot plate and cooled at room temperature. The mixture was then treated with $5 \mathrm{~mL}$ of $\mathrm{HClO}_{4}$, heated again on hot plate about $80^{\circ} \mathrm{C}$ until dense white fumes evolved and a clear digested solution was attained marking the completion of digestion process. The pyrex flasks were then cooled at ambient temperature and diluted to the final volume upto $25 \mathrm{~mL}$ with double distilled water. Blanks were also processed with the same sequence comprising of all the reagents but without serum sample (Mahmood et al. 2021).

\section{Serum elemental assay}

After digestion, concentrations of 20 toxic and essential elements ( $\mathrm{Fe}, \mathrm{Na}, \mathrm{Ca}, \mathrm{K}, \mathrm{Mg}, \mathrm{Zn}, \mathrm{Co}, \mathrm{Sr}, \mathrm{Pb}, \mathrm{Li}, \mathrm{Sb}, \mathrm{Cu}, \mathrm{Mn}, \mathrm{Ni}, \mathrm{Cr}, \mathrm{Ag}$ and $\mathrm{Cd}$ ) in the serum samples of EC and controls were analysed using flame atomic absorption spectrophotometer (Shamidzu AA-670, Japan). Levels of As, Se and Hg in the serum of all participants samples were quantified by GBC 932b plus atomic absorption spectrophotometer (GBC Scientific Equipments Pvt. Ltd. Australia). The instruments were operated with automatic background compensation under optimum analytical conditions which are shown in Table 1. To establish the precision, average concentration of each element in each serum sample was computed based on the measurement of 3 sub-samples that were run separately onto the spectrophotometer. For quality assurance and accuracy, standard reference material (Animal Serum, NIST SRM 1598a) was used. The results of data revealed excellent \%age recoveries range from 98 to $102 \%$ and given in Table 2. For comparison of the data, samples were also investigated at an independent laboratory and maximum of $5 \%$ difference was detected in the results of the two laboratories. All the chemical reagents used during the present study were got from E-Merck or BDH and they were of ultrahigh purity (certified >99.99\%) (Qayyum et al. 2020).

\section{Quantification of carcinoembryonic antigen (CEA)}

Carcinoembryonic antigen (CEA) is a family of related glycoprotein and is a representative biomarker that has been identified to be elevated in number of malignancies including lung, colorectal, pancreas and breast etc., (Bagaria et al. 2015). In esophagus cancer, CEA has been revealed as a diagnostic and prognostic marker, although its specificity has not been satisfactory (Yang et al. 2019). Therefore, the serum CEA level may be a pertinent index of tumor progression for EC patients. In serum, levels of CEA have been described to be elevated in EC patients (Bagaria et al. 2015). Serum concentrations of CEA were quantified by CEA-RIACT (Cisbio Bioassays, France) with immunoradiometric assay (IRMA) and are based on the principle of the 'sandwich' technique. On the CEA molecule, two monoclonal antibodies prepare against distant antigen sites. First is adsorbed on the solid phase (coated tube), the second which is radiolabelled with ${ }^{125}$, is used as a tracer and triggers the immunological reaction. The test is performed according to brochure as obtained from the manufacturer of the kit. The instrument is used for the quantification of CEA is Gamma Counter (STRATEC Biomedical Systems AG 75217 Germany).The radioactivity attached to the tube is proportional to the quantity of CEA initially present in the test (Mahmood et al. 2021).

\section{Statistical analysis}

Statistical analyses on elemental data were performed using the STATISTICA (6.0) software (StatSoft 1999). Descriptive analysis was conducted to find the basic statistical parameters such as range, mean, median, standard error, standard deviation, skweness and kurtosis in the serum of EC and

Page 3/23 
controls. Significant differences (at $p<0.05$ ) in the measured elemental concentrations for the cancerous patients and controls were measured using the Student's $t$ test. Wilcoxon rank-sum test was also used for the comparison of median elemental levels between various groups in each category. Probability level of $<0.05$ (two tailed) was considered statistically significant. Spearman correlation analysis was applied to inspect the mutual associations between the elemental levels.

\section{Multivariate analysis}

Multivariate apportionment of the elements in the serum of the EC patients and healthy donors was done by multivariate methods in terms of cluster analysis (CA) and principal component analysis (PCA). Cluster analysis (CA) is a set of techniques with relevance to quantitative form of classification which result in internal homogeneity and external heterogeneity. It is used to classify different objects into groups which have similar observations and their relationships, into a number of clusters depend on the observed values of several variables (Jolliffe 2002). The greater the similarity within a group and the larger the difference between groups, the better or more distinct clustering are appeared. The PCA has been used to be an efficient chemometric approach that allows summarizing information in large data set by means of smaller set of summary indices among the variables in a given system (Mahmood et al. 2021; Jolliffe 2002). It is a technique used as a descriptive tool desires no distributional assumptions. it is an adaptive exploratory method which can be used on numerical data of various types (Jolliffe and Cadima 2016). PCA is said to be a statistical data reduction technique, whereby new composite variables are constructed as linear combinations of the original independent variables while preserving as much of the data's variation as possible (Qayyum et al. 2020).

\section{Results And Discussion Demographic characteristics}

The demographic information of esophagus cancer patients $(n=378)$ and controls $(n=353)$ are presented in TDemographic characteristics The demographic information of esophagus cancer patients $(n=378)$ and controls $(n=353)$ are presented in Table 2. Majority of EC patients were of $\sim 52$ years old and healthy controls were $\sim 49$ years old on average basis. Among the selected subjects, $59 \%$ of patients were used tobacco in the form of cigarette, while $55 \%$ were cigarette smokers in the control group. Similarly, $48 \%$ and $58 \%$ of EC patients and healthy donors were from urban areas while $52 \%$ and $42 \%$ were belonged to rural areas, respectively. More than fifty percent of the patients and controls were vegetarian in their diets, while $49 \%$ of the controls and $46 \%$ of EC patients were non vegetarian in their food habit. Females (53\% of patients and $52 \%$ of controls) were greater than males (47\% of patients and $48 \%$ of controls) as shown in demographic Table 1. Both types of EC were diagnosed in patients from whom $56 \%$ were suffering from adenocarcinoma while $44 \%$ of patients were suffering from squamous cell carcinoma. Patients were also diagnosed at various stages of EC including $20 \%$ of the patients were identified at 1 st stage (stage-I), $30 \%$ at 2 nd stage (stage-II), $28 \%$ at 3rd stage (stage-III) and $22 \%$ at 4 th stage (stage-IV) (Table 2 ). All EC patients were newly diagnosed and were not under previous medications. Serum CEA levels were measured in EC patients with mean value 861.7 nano gram per milliliter (range, 218.5-4359). The cutoff value for CEA in the serum was set as $<7 \mathrm{ng} / \mathrm{mL}$ provided by the manufacturer company. Body mass index and esophagus cancer The body mass index (BMI) is the most commonly used measure of overweight and obesity. A high BMI has long been identified as a significant risk factor for many types of cancers including carcinoma of esophagus (Arnal et al. 2015). It is related to a higher incidence of gastroesophageal reflux which is strongly associated to the risk for Barrett esophagus (a metaplastic precursor state for adenocarcinomas) and EC (Turati et al., 2013). The risk of EC rises consistently with increasing $\mathrm{BMI}$. Further, a raised BMI is a risk factor for development of EAC, while a reduce BMI is a risk factor for development of ESCC (Lindkvist et al. 2014). The mean value of body mass index (BMI) $(23.98 \mathrm{~kg} / \mathrm{m} 2$ (range, 21.57-24.91)) was considerably higher in the EC patients than the controls (18.05 kg/m2 (range 16.87-20.61)) as observed in the present study (Table 2). A number of studies have been conducted to explore the effects of BMI on the prognosis of EC patients (Gu et al. 2019). Nonetheless, the relationship between BMI and prognosis remains inconclusive and require further elucidation. Some observational studies advocated that BMI did not influence the survival of esophagus carcinoma patients. Others have advocated that a high BMI is an independent prognostic factor for the carcinoma of esophagus (Gu et al. 2019). Accumulation of adipose tissue enhances the levels of endogenous hormones, including sex steroids, insulin, insulin growth factor-1, increasing cell proliferation, impairing apoptosis, consequently favoring preneoplastic and neoplastic cell growth. Although the true pathophysiology underlying this linkage remains unclear, however, obesity can lead to, facilitating gastroesophageal reflux and esophagitis, metabolic disturbances, such as increased levels of proinflammatory cytokines and adipokines, which may increase risk of carcinoma (Chen et al. 2012). Distribution of the elemental levels in the serum of esophagus cancer patients and controls The distribution of selected essential and toxic elemental levels ( $\mu \mathrm{g} / \mathrm{g}$, wet weight) as basic statistical parameters in the serum of EC patients $(n=378)$ and controls $(n=353)$ are summarized in Table 3. Minimum and maximum levels were depicting that selected elements mostly pointed out wide range of their concentrations. For esophagus carcinoma patients, comparatively elevated average levels were obtained for $\mathrm{Na}$ (mean, $244.7 \mu \mathrm{g} / \mathrm{g}$, range, 204.8-354.8 $\mu \mathrm{g} / \mathrm{g}), \mathrm{K}(\mathrm{mean}, 171 \mu \mathrm{g} / \mathrm{g}$, range, $150.8-199 \mu \mathrm{g} / \mathrm{g}$ ), Fe (mean, $59.98 \mu \mathrm{g} / \mathrm{g}$, range, 39.28-69.90 $\mu \mathrm{g} / \mathrm{g}$ ), Ca (mean, $28.68 \mu \mathrm{g} / \mathrm{g}$, range, 12.33-47.34 $\mu \mathrm{g} / \mathrm{g}$ )and Mg (mean, 15.17 $\mu \mathrm{g} / \mathrm{g}$, range, $10.18-23.62 \mu \mathrm{g} / \mathrm{g}$ ) followed by, moderately lower levels of Zn (mean, $3.616 \mu \mathrm{g} / \mathrm{g}$, range, 0.333-6.588 $\mu \mathrm{g} / \mathrm{g}$ ), Co (mean, $2.407 \mu \mathrm{g} / \mathrm{g}$, range, 1.212-2.987 $\mu \mathrm{g} / \mathrm{g}$ ), Sr (mean, $1.418 \mu \mathrm{g} / \mathrm{g}$, range,

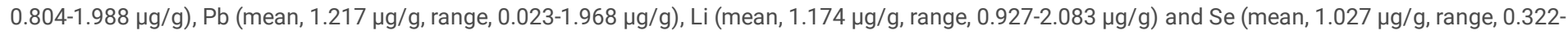
$1.985 \mu \mathrm{g} / \mathrm{g}$ ). However, average concentrations of Sb (mean, $0.970 \mu \mathrm{g} / \mathrm{g}$, range, 0.167-1.642 $\mu \mathrm{g} / \mathrm{g})$, Cu (mean, 0.933 $\mu \mathrm{g} / \mathrm{g}, \mathrm{range}, 0.025-1.821 \mu \mathrm{g} / \mathrm{g})$, Mn (mean, $0.819 \mu \mathrm{g} / \mathrm{g}$, range, 0.050-1.962 $\mathrm{gg} / \mathrm{g}$ ), Ni (mean, $0.539 \mu \mathrm{g} / \mathrm{g}$, range, 0.006-5.299 $\mu \mathrm{g} / \mathrm{g}), \mathrm{Cr}$ (mean, $0.444 \mu \mathrm{g} / \mathrm{g}$, range, $0.004-2.101 \mu \mathrm{g} / \mathrm{g}), \mathrm{Ag}(\mathrm{mean}, 0.325 \mu \mathrm{g} / \mathrm{g}$,

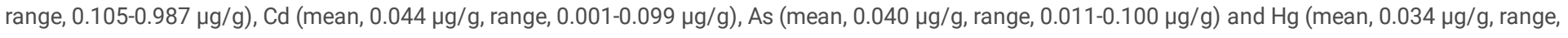
$0.010-0.099 \mu \mathrm{g} / \mathrm{g}$ ) were evaluated at lowest concentrations in the serum of EC patients. Overall, average elemental levels exhibited following order in the serum of EC participants: $\mathrm{Na}>\mathrm{K}>\mathrm{Fe}>\mathrm{Ca}>\mathrm{Mg}>\mathrm{Zn}>\mathrm{Co}>\mathrm{Sr}>\mathrm{Pb}>\mathrm{Li}>\mathrm{Se}>\mathrm{Sb}>\mathrm{Cu}>\mathrm{Mn}>\mathrm{Ni}>\mathrm{Cr}>\mathrm{Ag}>\mathrm{Cd}>\mathrm{As}>\mathrm{Hg}$. High values of $\mathrm{SD}$ and $\mathrm{SE}$ as well as unlike mean and median concentrations values of measured elements illustrated that majority of the elements showed unsystematic distribution. In terms of large SD and SE values, maximum dispersion were revealed by $\mathrm{Na}, \mathrm{K}, \mathrm{Ca}$, Fe and Mg; therefore, these elements were randomly distributed in the serum of EC patients which revealed non-Gaussian distribution pattern. Some of the elements ( $\mathrm{Cd}, \mathrm{As}, \mathrm{Ag}, \mathrm{Sr}$ and $\mathrm{Hg}$ ) depicted somewhat normal distribution pattern as evidenced by lower SD and SE values which exhibited Gaussian distribution. Elements like $\mathrm{Ni}, \mathrm{Li}, \mathrm{Cr}, \mathrm{Ag}, \mathrm{Hg}$ and $\mathrm{K}$ showed asymmetrical distribution as shown 
by large kurtosis and skewness values, while the rest of the elements exhibited relatively symmetrical distribution in the serum of EC patients (Table 3 ). In the case of controls (Table 3), on the average, elemental concentrations were found dominant for $\mathrm{Na}$ (mean, $220.8 \mu \mathrm{g} / \mathrm{g}, \mathrm{range}, 104.4-277.1 \mu \mathrm{g} / \mathrm{g}$ ), followed by, $\mathrm{K}$ (mean, $199.4 \mu \mathrm{g} / \mathrm{g}$, range, 101.8-267.4 $\mu \mathrm{g} / \mathrm{g}$ ), Fe (mean, $91.22 \mu \mathrm{g} / \mathrm{g}$, range, 70.51-99.52 $\mu \mathrm{g} / \mathrm{g}$ ), Ca (mean, $42.84 \mu \mathrm{g} / \mathrm{g}$, range, $27.48-59.18 \mu \mathrm{g} / \mathrm{g}$ ), and Mg (mean, $18.07 \mu \mathrm{g} / \mathrm{g}$, range, $6.240-27.17 \mu \mathrm{g} / \mathrm{g}$ ). However, relatively lower average levels were recorded for Zn (mean, $5.883 \mu \mathrm{g} / \mathrm{g}, \mathrm{range}, 3.441-7.769 \mu \mathrm{g} / \mathrm{g}$ ), Co (mean, $3.408 \mu \mathrm{g} / \mathrm{g}$, range, 2.525-3.956 $\mu \mathrm{g} / \mathrm{g})$, Se (mean, $1.979 \mu \mathrm{g} / \mathrm{g}$, range, 1.064-3.921 $\mu \mathrm{g} / \mathrm{g}), \mathrm{Sr}$ (mean, $1.856 \mu \mathrm{g} / \mathrm{g}$, range, $1.096-2.438 \mu \mathrm{g} / \mathrm{g}), \mathrm{Li}(\mathrm{mean}, 1.791 \mu \mathrm{g} / \mathrm{g}$, range, 0.976-3.836 $\mu \mathrm{g} / \mathrm{g}$ ), Mn (mean, $1.339 \mu \mathrm{g} / \mathrm{g}$, range, 0.049-1.882 $\mathrm{gg} / \mathrm{g}$ ) and Sb (mean, $1.213 \mu \mathrm{g} / \mathrm{g}$, range, 0.128-3.813 $\mu \mathrm{g} / \mathrm{g}$ ), Cu (mean, 0.603 $\mu \mathrm{g} / \mathrm{g}$, range, 0.034-0.965 $\mu \mathrm{g} / \mathrm{g}$ ), Pb (mean, $0.515 \mu \mathrm{g} / \mathrm{g}$, range, 0.003-0.995 $\mu \mathrm{g} / \mathrm{g}$ ), Ni (mean, $0.295 \mu \mathrm{g} / \mathrm{g}$, range, 0.045-0.817 $\mu \mathrm{g} / \mathrm{g}), \mathrm{Ag}(\mathrm{mean}, 0.275 \mu \mathrm{g} / \mathrm{g}, \mathrm{range}, 0.011-0.874$ $\mu \mathrm{g} / \mathrm{g}$ ), $\mathrm{Cr}$ (mean, $0.254 \mu \mathrm{g} / \mathrm{g}$, range, 0.024-0.392 $\mu \mathrm{g} / \mathrm{g}), \mathrm{Hg}$ (mean, $0.046 \mu \mathrm{g} / \mathrm{g}$, range, 0.011-0.120 $\mu \mathrm{g} / \mathrm{g}$ ), Cd (mean, $0.025 \mu \mathrm{g} / \mathrm{g}$, range, $0.020-0.035 \mu \mathrm{g} / \mathrm{g}$ ) and As (mean, $0.022 \mu \mathrm{g} / \mathrm{g}$, range, $0.010-0.089 \mu \mathrm{g} / \mathrm{g}$ ) were found lowest levels in the serum of controls. On the mean scale, the decreasing trend of elemental levels in the serum of controls revealed following order: $\mathrm{Na}>\mathrm{K}>\mathrm{Fe}>\mathrm{Ca}>\mathrm{Mg}>\mathrm{Zn}>\mathrm{Co}>\mathrm{Se}>\mathrm{Sr}>\mathrm{Li}>\mathrm{Mn}>\mathrm{Sb}>\mathrm{Cu}>\mathrm{Pb}>\mathrm{Ni}>\mathrm{Ag}>\mathrm{Cr}>\mathrm{Hg}>\mathrm{Cd}>\mathrm{As}$. Among the selected elements, $\mathrm{Fe}, \mathrm{Na}, \mathrm{Ca}$, Fe and Mg exhibited relatively higher dispersion as shown by higher SD and SE values. Other metals (Cd, $\mathrm{Cr}$, As, $\mathrm{Hg}$, Ag and $\mathrm{Ni}$ ) noted somewhat normal distribution pattern manifested by relatively small SD and SE values. Increased skewness and kurtosis values for Se, Mn, As, Cr, and Cu supported asymmetrical distribution of these elements while modest skewness values for rest of the elements represented moderately symmetrical distribution in the serum of controls (Table 3). Comparison of the essential/toxic elemental levels in the serum of esophagus cancer patients and controls $\mathrm{A}$ systematic and detailed comparison (two sample t-test) of the average elemental levels measured in the serum of the patients and controls manifested that mean $\mathrm{Cu}, \mathrm{Ni}, \mathrm{Cr}, \mathrm{Cd}, \mathrm{Pb}, \mathrm{As}$ and $\mathrm{Ag}$ concentrations were observed to be significantly increased in the serum of EC patients $(\mathrm{p}<0.05)$, while mean levels of Fe, $\mathrm{Ca}, \mathrm{Zn}, \mathrm{Co}, \mathrm{Mg}$, Se, Li and Mn were observed to be moderately higher in serum of the controls $(\mathrm{p}<0.05)$. However, statistically non-significant differences at $\mathrm{p}<$ 0.05 were found for average concentrations of $\mathrm{Sb}, \mathrm{Se}, \mathrm{K}$ and $\mathrm{Sr}$ in the serum of the EC patients and healthy donors. Similarly, median concentrations of the toxic/essential elements were also compared by Wilcoxon rank sum test which exhibited statistically significant differences ( $p<0.05)$ for $\mathrm{Cr}$, $\mathrm{Pb}$, $\mathrm{Ni}, \mathrm{Mn}, \mathrm{Co}$, $\mathrm{Fe}$ and $\mathrm{Cu}$ in the serum samples of two groups. The comparison between EC patients and controls revealed therefore a buildup of toxic elements ( $\mathrm{Cr}$, Cd, $\mathrm{Pb}$, As and $\mathrm{Ni}$ ) and deficiency of the essential elements ( $\mathrm{Se}, \mathrm{Zn}, \mathrm{Fe}$ and $\mathrm{Ca}$ ) in case of the cancerous patients than the healthy donors. These elevated concentrations of toxic elements found in the EC patients are proven carcinogen and their higher levels can further promote the carcinogenesis (Yang et al. 2021; Xie et al. 2019; Kazi et al. 2015). Moreover, the deficiencies of essential elements (i.e., Fe, Zn and Se) are linked to poor immunity and excessive accumulation of the reactive oxygen species (ROS) which further deteriorate the health of the patients (Lin et al. 2019). Significant differences in the levels of various toxic/trace elements in the blood, hairs and tissues of the EC cancer patients compared with the healthy controls have been reported in some studies (Rahman and Singh 2019; Kazi et al. 2915). Thus foregoing discussion clearly depicted that the relative distribution of the elements in the serum of EC patients is considerably different when compared to controls, which also pointed out the particular role of the elements in the development of the carcinoma (Dar et al. 2008; Lin et al. 2017). For instance $\mathrm{Cd}$ is a carcinogenic agent and a fatally toxic pollutant (Balali-Mood et al. 2021). It mimics Zn's divalent chemical state, so it can interfere with the DNA Zn binding site (Rahman et al. 2019). Various studies disclosed that Cd inhibits repairing of DNA damage by causing hindrance in its principle steps (Lin et al. 2017). Cadmium is included in group 1 carcinogen, having strong association with cancer as its chronic and long term exposure could cause malignant tumors to different organs such as brain, bladder, head, neck, breast, kidney, liver, prostate, lung and esophagus cancers (Jiang et al. 2021). Chromium is a toxic to human health and is classified as group I carcinogen by IARC (Balali-Mood et al. 2021). Following Fenton chemistry, Cr also interacts with hydrogen peroxide, thus producing a wide variety of ROS such as superoxide, singlet oxygen and hydroxyl radicals (Balali-Mood et al. 2021). In this way, Cr induced oxidative stress which result in cell DNA damage and breaks of DNA strand along with the formation of unstable DNA protein cross-links as well as Cr-DNA adducts (Rahman et al. 2019). There are epidemiological evidences that $\mathrm{Cr}$ and its compounds are positively associated with various types of carcinomas including respiratory, lung and stomach cancers (IARC 2018). Exposure of As to cells and tissues modulates the signaling pathways that involved in adverse processes including enhances cell proliferation, differentiation, blocking physiological apoptosis and are linked to the development of carcinoma (IARC 2012; Nurchi et al. 2020). The IARC and Environmental Protection Agency of US has classified As as a class I human carcinogen (Balali-Mood et al. 2021). Moreover, As potentiates/stimulates angiogenesis, mutagenesis, cytotoxic, and clastogenesis of other carcinogens which in turn to promote cancer development (Xu et al. 2017). Several epidemiological studies have claimed that exposure to As has been strongly linked with carcinomas in human organs such as the kidney, bladder, lung, liver, prostate and especially the skin (Nurchi et al. 2020; Xu et al. 2017). Carcinogenesis of Cu has to be assumed to increase oxidative stress via its involvement in the activation of hydrogen peroxide and later on, to produce more ROS like hydroxyl radicals that damage cellular DNA, proteins and lipids (Xie et al. 2019; Yang et al. 2021). Multiple reports have been published on the aberrant levels of Cu in malignant tissues of tumor-bearing mice and cancerous patients (Xu et al. 2017). Higher levels of Cu have been found in the patients of breast, ovary, lung, and stomach cancers (Michalczyk and Cymbaluk-Ploska 2020). Some studies disclosed high concentration of $\mathrm{Cu}$ in the blood of EC patients in comparison to healthy controls (Ahmad et al. 2011) while some studies explored lower concentration of $\mathrm{Cu}$ in the tissue of carcinoma patients as compared to controls (Joshaghani et al. 2017). In a cohort study, Cu was found to increase the risk of ESCC, even found in the tissue segments of esophagus (Hashemian et al. 2015). Goyal and its coworkers reported high concentration of $\mathrm{Cu}$ in the serum of esophagus carcinoma patients in comparison to healthy controls (Goyal et al. 2006). Recent literature also found high concentration of $\mathrm{Cu}$ in the serum of esophagus malignant patients as comparison to healthy controls (Yang et al. 2021; Dar et al. 2008). Lead also produces toxicity via its capability to substitute univalent cations (i.e., Na+) as well as divalent cations (i.e., Fe2+, Mg2+, Ca2+) (Balali-Mood et al. 2021). By this way, Pb badly affects numerous basic natural functions of human body internal administration as well as cellular processes including release of neurotransmitters, enzyme regulation, ionic transportation, apoptosis, protein folding and maturation, cell adhesion and intra and intercellular signaling (Flora et al. 2012). In rodent cells, exposure to $\mathrm{Pb}$ induced gene mutations, sister chromatid exchanges, morphological transformations as well as to increase anchorage independence in diploid human fibroblasts (Wallace and Djordevic 2020). Experimental studies advocate that increased incidences of kidney cancer, lung, brain, and hematopoietic cancers, among rodents exposed to Pb (Kim et al. 2019; Balali-Mood et al. 2021). Exposure to Pb in battery manufacturing, smelting, and pigment production industries workers revealed high levels of $\mathrm{Pb}$ and its compounds and these studies claimed that there may be excess risks for lung and stomach cancers among these workers (Rahman and Singh 2019). In a case-control study, Ahmad et al. (2011) investigated the concentration of Pb in different specimens of EC patients was higher as compared to controls. Nickel induced carcinogenicity, hepatotoxicity, nephrotoxicity, genotoxicity and neurotoxicity (Das et al. 2018). Other adverse effects of Ni are in lipid peroxidation and oxidative DNA damage (Lee et al. 2016). Nickel produces relatively low levels of ROS in cells which promotes oxidative DNA damage, inhibition of DNA repair activity and interferes in the activation of some transcription factors 
(Chen et al. 2017; Xu et al. 2017). The IARC has concluded that exposure to Ni is linked with an increased risk of lung and sinonasal cancers based on results from many studies (Das et al. 2018). Lee et al. (2016) inspected the content of Ni high and low rate EC prevalence areas and explored that concentration of Ni was higher in high rate areas than in low rate areas of EC. In a cohort study, workers of biggest Ni production enterprise in China were inspected and disclosed that deaths of these workers were due to different types of cancers including esophagus, lung, stomach and liver cancers (Ma et al. 2014; Lee et al. 2016). In addition, the means Ni was elevated in the serum of ESCC compared to controls as examined by Lin et al. (2017). Various studies advocated that Ca exerts shielding effect via promoting apoptosis, inhibiting cell cycle and also the generation of tumors (Shah et al. 2020). Protective effect of Ca was found in a study against ESCC and EAC in men (Park et al. 2009). Hashemian et al. (2015) investigated the possible association of nutritional Ca with EAC cancer and found an inverse association with ESCC. Similar results were found in many others case-control studies (Jessri et al. 2011). However, there are some studies indicating not any relationship of Ca with EC (Lu et al. 2006; Hashemian et al. (2015). Animal studies also found out possible association of Ca with cancer. In a mice study, mice was fed with high Ca meal and observed inhibition of tumor formation, cell growth and metastasis as well (Ju et al. 2012). Higher dietary Ca intake is related to a lower risk of EC particularly in ESCC patients as claimed in Asian populations (Dawsey et al. 2014). Iron overload is associated with increasing incidence rate and risk of carcinoma. Tumor patients may also have insufficient serum Fe (Khan et al. 2020). Moreover, Fe is involved in the initiation, growth, progression, and metastasis of cancer (Jung et al. 2019; Yang et al. 2021). Excess Fe plays an important role in tumor growth and tumor cell proliferation, and hence could be a cause of liver, gastrointestinal, esophagus, stomach and colorectum cancers (Lagergren et al. 2016). There are epidemiological proofs that give indication about the positive association of Fe with EC (Torti and Torti, 2011). Numerous studies showed excess usage of dietary haem Fe has potentially enhanced the risk of EAC in humans (Ward et al. 2012; Yang et al. 2021). It was also confirmed by a cohort study that excess of Fe is potentially carcinogenic and potentially enhances the risk EC (Ward et al. 2012). The serum Fe level of patients with EC was significantly higher compared with healthy controls (Yang et al. 2021). Selenium is a well-known electrometalloid and is mostly famous due to its anticancerous properties and chemopreventive effects (Keshavarzi et al., 2012). Selenium is serving as an essential component in selenoproteins and can reduce oxidative stress and limit DNA damage, both of which have been associated to carcinoma risk (Wei et al. 2004). Previous studies have demonstrated that Se deficiency/insufficiency may be linked to a variety of degenerative diseases, including cardiovascular disorders, immune dysfunctions and cancer (Keshavarzi et al. 2012; Wei et al. 2004). Level of high Se exposure Se may have different effects on specific types of carcinomas. It alleviates the risk of lung carcinoma, breast carcinoma, prostate carcinoma, gastric carcinoma and esophageal carcinoma (Cai et al. 2016). Selenium level in the serum of esophagus carcinoma patients was significantly lower than the healthy controls (Goyal et al. 2006; Yang et al. 2021). In Finland and the Netherlands, low Se concentrations were linked to an enhanced risk of rising ESCC and other carcinomas as shown in large cohort studies (Pritchett et al. 2017). Zinc acts as a cofactor of superoxide dismutase for quenching of free radicals ultimately providing shield from cancer (Kazi et al. 2015). Various studies have explored that high content of $Z \mathrm{n}$ has an inverse association with different types of cancers (Fong et al. 2001; Joshaghani et al. 2017). Zinc deficiency promote mutagenesis, cell proliferation, differentiation, inhibit DNA synthesis and DNA repair as well as reduced antioxidant balance, having positive association with EC (Dar et al. 2010; Prasad 2014). Hashemian et al. (2015) stated that Zn exert preventive effect against ESCC and have an inverse association with it. Several studies recorded that $\mathrm{Zn}$ level was found lower in EC patients than the controls (Yang et al. 2021; Dar et al. 2008). Goyal and his coworkers also disclosed lower level of Zn found in the serum of EC patients as compared to healthy controls (Goyal et al. 2006). Several retrospective and prospective human population-based surveys have underlined the role of Zn deficiency as a risk factor for development of esophagus carcinoma (Nouri et al. 2008). A case control study was conducted in India, which evaluated that EC patients have considerably low mean concentration of Zn when compared to controls (Dar et al. 2008; Joshaghani et al. 2017). In other case-control study that was conducted in Pakistan, Zn value was recorded much lower in the different biological specimens of EC patients in comparison to healthy controls (Ahmad et al. 2011). On contrary, elevated level of $\mathrm{Zn}$ in the serum of EC patients compared to controls has been examined in some studies (Yang et al. 2021). Correlation study The data on element-to-element correlation in the serum of EC patients are explored in Table 4 (below the diagonal), wherein the bold r-values are significant at $\mathrm{p}<0.05$. In case of EC patients, strong and significant positive correlations were noted between As-Sr $(r=0.75)$, $\mathrm{Cr}-\mathrm{Cd}(\mathrm{r}=0.73)$, Ag-Li (r=0.71), Cu-Cr ( $r=0.70)$, Cu-Ni ( $r=0.67)$, Ni-Mn ( $r=0.66)$, Cr-As ( $r=0.65)$, Fe-Cd ( $r=0.65), \mathrm{Cr}-\mathrm{Pb}(r=0.64), \mathrm{Zn}-\mathrm{Ni}(\mathrm{r}=0.61)$ and Ca-Cd ( $r=0.60)$. In addition, some statistically significant relationships were detected among Ag-Sb ( $r=0.59)$, Sr-Na ( $r=0.59), \mathrm{Li}-\mathrm{Ni}(r=0.59), \mathrm{Ag}-\mathrm{K}(\mathrm{r}=0.59), \mathrm{Li}-\mathrm{Co}(\mathrm{r}=0.58), \mathrm{Ca}-\mathrm{Sr}(\mathrm{r}=0.57), \mathrm{Fe}-\mathrm{Co}$ $(r=0.57), \mathrm{Sb}-\mathrm{Co}(r=0.57), \mathrm{Cu}-\mathrm{Ag}(\mathrm{r}=0.57), \mathrm{Hg}-\mathrm{K}(\mathrm{r}=0.56), \mathrm{Hg}-\mathrm{Mn}(\mathrm{r}=0.56), \mathrm{Sr}-\mathrm{Se}(\mathrm{r}=0.56), \mathrm{Cu}-\mathrm{Na}(\mathrm{r}=0.55), \mathrm{Cu}-\mathrm{Hg}(\mathrm{r}=0.55), \mathrm{Zn}-\mathrm{Cd}(\mathrm{r}=0.54), \mathrm{As}-\mathrm{K}(\mathrm{r}=0.54), \mathrm{Mg}-\mathrm{Ni}$ $(r=0.53), \mathrm{Ag}-\mathrm{Se}(\mathrm{r}=0.53), \mathrm{Cd}-\mathrm{Pb}(\mathrm{r}=0.52), \mathrm{Zn}-\mathrm{Co}(\mathrm{r}=0.52), \mathrm{Na}-\mathrm{k}(\mathrm{r}=0.52)$ and Li-Mg $(r=0.51)$. The significant positive correlations among the elements showed their probable communal variations/sources in the serum samples of EC patients. Some of the elemental pairs such as Sb-Pb $(r=-0.57)$, As-Cu $(r=-0.56)$, $\mathrm{Mg}-\mathrm{Cu}(r=-0.55)$, Se-As $(r=-0.54)$, Ni-Fe $(r=-0.52)$ and Mg-Na $(r=-0.51)$ showed inverse relationships and opposing distributions in the serum of EC patients, which revealed the depletion or enrichment of specific elements at the cost of others. The correlation study pointed out mutual association between $\mathrm{Cu}, \mathrm{Mn}, \mathrm{Pb}, \mathrm{Li}, \mathrm{Ag}$ and $\mathrm{Ni}$ in the serum of the EC patients while one of the major electrolytes $(\mathrm{K})$ revealed contrasting variations with most of the elements thus illustrating the disproportional distribution of the elements in the serum of cancerous patients. Seemingly, positive relationships of toxic metals ( $\mathrm{Ni}$, Cd, As, $\mathrm{Hg}$, $\mathrm{Cu}$, and $\mathrm{Co}$ ) with essential elements ( $\mathrm{Fe}, \mathrm{Ca}, \mathrm{K}, \mathrm{Zn}$ and $\mathrm{Na}$ ) revealed a build-up of the toxic elements in serum of EC patients. Some epidemiological and clinical studies advocated the role of iron, lead, calcium and cadmium in the progression esophagus malignancy (Kim et al. 2019; Rahman and Singh 2019). Further these studies exhibited the critical role of some of these metals in the generation of oxidative stress via free radicals which later on resulted in development of neoplasm in esophagus (Balali-Mood et al. 2021). In the case of controls, the correlation study exhibited significantly diverse mutual associations between the elements as shown in Table 4 (above the diagonal). Statistically, strong/significant correlations $(\mathrm{p}<0.05)$ were noted between Ni-Pb $(r=0.67)$, Ca-Sr $(r=0.65)$, Cd-As ( $r=0.64)$, Cr-As ( $r=0.62), \mathrm{Cd}-\mathrm{Sr}(\mathrm{r}=0.61)$ and Cu-Co ( $r=0.60)$. Furthermore, statistically significant correlations were observed between Fe-Pb ( $r=0.68), \mathrm{Mn}-$ $\mathrm{Hg}(\mathrm{r}=0.59), \mathrm{Mg}-\mathrm{Mn}(\mathrm{r}=0.58), \mathrm{Cr}-\mathrm{Pb}(\mathrm{r}=0.58), \mathrm{As}-\mathrm{Ag}(\mathrm{r}=0.57), \mathrm{Ca}-\mathrm{Na}(\mathrm{r}=0.57), \mathrm{Pb}-\mathrm{As}(\mathrm{r}=0.55), \mathrm{Ca}-\mathrm{Mg}(\mathrm{r}=0.55), \mathrm{Fe}-\mathrm{As}(\mathrm{r}=0.55), \mathrm{Ca}-\mathrm{Zn}(\mathrm{r}=0.54), \mathrm{Ag}-\mathrm{Mg}(\mathrm{r}=0.54), \mathrm{Fe}-$ $\mathrm{Se}(\mathrm{r}=0.53), \mathrm{Cd}-\mathrm{Co}(\mathrm{r}=0.53), \mathrm{Cr}-\mathrm{Sb}(\mathrm{r}=0.52), \mathrm{Zn}-\mathrm{Ag}(\mathrm{r}=0.51), \mathrm{Pb}-\mathrm{Hg}(\mathrm{r}=0.51)$ and $\mathrm{Fe}-\mathrm{Cr}(\mathrm{r}=0.50)$. Some significant negative correlations were also shown among K-Na ( $r=-0.59)$, As-Cu ( $r=-0.59), \mathrm{Hg}-\mathrm{Ag}(r=-0.57)$, Cu-Fe $(r=-0.55), \mathrm{K}-\mathrm{Ca}(r=-0.54)$, Li-Ni $(r=-0.53), \mathrm{Sb}-\mathrm{Zn}(\mathrm{r}=-0.50)$ and Co-Li $(r=-0.50)(\mathrm{Table} 4)$. Of note, unlike the patients, most of the essential elements ( $\mathrm{Zn}, \mathrm{Ca}, \mathrm{Na}, \mathrm{Fe}, \mathrm{K}$ and $\mathrm{Fe}$ ) showed significant mutual relationships in the serum of healthy donors. Overall, the correlation behavior of selected essential and toxic elements in the serum of EC was considerably divergent compared with controls, which may be attributed to the disproportions and imbalances of the elements in the cancerous patients. Comparison of the essential/toxic elemental levels based on demographic characteristics Mean essential/toxic elemental levels revealed in the serum samples of different demographic groups of EC patients and healthy donors/controls are compared by t-test (two-tailed, assuming unequal variance). Smoking-based comparison in the average levels of selected essential/toxic 
elements in the serum of esophagus carcinoma patients and healthy subject is displayed in the Fig. 1a which showed higher $\mathrm{Cu}, \mathrm{Ni}$, $\mathrm{Cr}, \mathrm{Pb}, \mathrm{Cd}$, $\mathrm{As}$ and $\mathrm{Ag}$ levels in smoker patients than the smoker controls. Mean values of $\mathrm{Sb}, \mathrm{Mn}, \mathrm{Co}, \mathrm{Mg}, \mathrm{K}, \mathrm{Se}, \mathrm{Zn}, \mathrm{Hg}, \mathrm{Fe}, \mathrm{Ca}$ and $\mathrm{Zn}$ were elevated in smoker controls than smoker patients. Nevertheless, average values of $\mathrm{Hg}, \mathrm{Se}, \mathrm{Zn}, \mathrm{K}, \mathrm{Sb}, \mathrm{Mn}, \mathrm{Fe}, \mathrm{Co}, \mathrm{Ca}$ and Se were recognized to be considerably higher in the serum of non-smoker controls than non-smoker patients. In the case of non-smoker patients, average levels of $\mathrm{Li}, \mathrm{Ag}, \mathrm{As}, \mathrm{Cd}, \mathrm{Cr}$, Ni and Cu were pointed out to be significantly elevated in the serum as compared to non-smoker controls as displayed in Fig. 1a. Cigarette smoking also influenced/enhanced risk of EC, no matter expressed as the frequency, duration/cumulative smoking amount (Li et al. 2014). Many components of tobacco contain carcinogens which may contribute to the pathogenesis of EC (Wang et al. 2017). There is a 1.5-to four-fold increase in EC risk among smokers as claimed in some studies; however in other studies no association has been established (Yang et al. 2017). Comparison of average levels of selected essential/toxic elements in the serum of the esophagus carcinoma patients and healthy donors depend on their abode is showed in the Fig. 1b. Comparative evaluation of the elements revealed approximately equivalent contributions of $\mathrm{Zn}, \mathrm{As}, \mathrm{Sr}, \mathrm{Na}, \mathrm{K}, \mathrm{Mg}$ and $\mathrm{Fe}$ in the serum of urban and rural esophagus carcinoma patients. However, average $\mathrm{Cu}, \mathrm{Ni}$ and $\mathrm{Ag}$ contents depicted significantly higher contribution in the serum of urban patients than rural patients, while average concentrations of $\mathrm{Se}$, $\mathrm{Cr}$, Sb and $\mathrm{Cd}$ were found to be comparatively higher in the serum of rural patients than the urban patients. In case of healthy donors, relatively higher mean concentrations of Ca, $\mathrm{Fe}, \mathrm{Zn}, \mathrm{Se}, \mathrm{K}, \mathrm{Co}, \mathrm{Mg}, \mathrm{Mn}$ and $\mathrm{Sb}$ were recorded in the serum of urban controls compared with the urban patients. Mean Co, K, Se, Hg, Ag, Zn, Fe and Ca were relatively elevated in the serum of rural healthy donors than rural patients as shown in Fig. Nonetheless, average concentrations of $\mathrm{Mn}, \mathrm{Mg}, \mathrm{Na}$, $\mathrm{Li}$, $\mathrm{Sr}$ and $\mathrm{Ni}$ were almost comparable in both urban and rural controls as shown in Fig.1b. During recent years, food contaminations by chemicals such as toxic elements have become inevitable problems from the environment. Recent data supports that there is an association between some dietary components and risk of carcinogenic process in esophagus (Liu et al. 2017). However, the association is not yet clear. Similarly, the results of several epidemiological studies revealed that some dietary patterns are significantly associated with an increased risk of ESCC (Jessri et al. 2011). Use high starch food and low quantity of fresh fruits as well as vegetables have been linked to process of EC (Liu et al. 2017). Epidemiological investigations along different lines revealed adequate consumption of fruit and vegetable was significantly related with decreased risk of EC which could play a role in protecting against this malignancy (Jessri et al. 2011). Dietary-based (vegetarian and non vegetarian) comparison of the selected elements in the serum of the EC patients and controls is shown in Fig. $1 \mathrm{c}$, revealed comparatively high mean level of $\mathrm{Cu}, \mathrm{Ni}, \mathrm{Ag}$ and $\mathrm{Li}$ in the vegetarian patients than the non-vegetarian counterparts which exposed elevated levels of $\mathrm{Mn}$, Se, $\mathrm{Ca}, \mathrm{Cd}$ and $\mathrm{Cr}$ in their serum. Nevertheless, average concentrations of $\mathrm{Fe}, \mathrm{Zn}, \mathrm{Pb}, \mathrm{As}, \mathrm{Sr}, \mathrm{Hg}, \mathrm{Na}, \mathrm{K}$ and $\mathrm{Mg}$ were found to be comparable in both patient groups. In the case of healthy donors, mean elemental $\mathrm{Co}, \mathrm{Mn}, \mathrm{Sb}, \mathrm{Se}, \mathrm{Zn}, \mathrm{Fe}$ and $\mathrm{Ca}$ contents were found to be higher in the serum of non-vegetarian controls as compared to non vegetarian patients. Similarly, average $\mathrm{Hg}$, Se, $\mathrm{Ca}, \mathrm{K}, \mathrm{Fe}, \mathrm{Mn}, \mathrm{Zn}$ and Co levels were maximum in the serum of vegetarian controls than vegetarian EC patients. Besides, average concentrations of $\mathrm{Cu}, \mathrm{Cd}, \mathrm{Pb}, \mathrm{As}, \mathrm{Ni}, \mathrm{Cr}$, $\mathrm{Ag}$ and $\mathrm{Li}$ were found to be considerably elevated in the serum of vegetarian patients than non vegetarian controls as shown in Fig. 1c. Carcinoma of esophagus continues to be a man dominant malignancy. Esophagus carcinoma is 2 to 3 times more common in males than females worldwide (Lin et al. 2017). Gender-based comparison as shown in Fig. 1d revealed comparatively high average concentrations of $\mathrm{Cu}, \mathrm{Ni}, \mathrm{Cr}, \mathrm{Pb}$, and $\mathrm{Ag}$ in the serum of female patients than female controls. Whereas elemental $\mathrm{Zn}$, Sd, $\mathrm{Hg}$, Se and $\mathrm{Sb}$ contents were higher in the serum of female controls. Average $\mathrm{Cu}, \mathrm{Ni}, \mathrm{Cr}, \mathrm{Cd}, \mathrm{Pb}$, As and $\mathrm{Sb}$ levels were found elevated in the serum of male EC patients when compared to male controls. Similarly, mean $\mathrm{Ca}, \mathrm{Fe}, \mathrm{Zn}, \mathrm{Ag}, \mathrm{Hg}$, Se, $\mathrm{K}$ and $\mathrm{Co}$ contents revealed higher in the serum of male controls as compared to male patients. Nevertheless, mean levels of Mn, Co, Mg, K, Na, Li, Sr, Fe and Ca were exhibited to be nearly equivalent in both patient groups (Fig. 1d). Hence, discovery of a credible and strong causal association between trace elements and carcinoma of the esophagus may create a new frontier for the prevention and management of an established disease. Comparison of the elemental levels based on types and stages Comparative evaluation of the average toxic/essential elemental levels in the serum of both types (adenocarcinoma and squamous cell carcinoma) of the EC patients is displayed in Fig. 2. The patients suffered from adenocarcinoma showed relatively elevated levels of $\mathrm{Cu}, \mathrm{Ni}, \mathrm{Pb}, \mathrm{Li}$, $\mathrm{Sb}$ and $\mathrm{Mn}$ than squmaous cell carcinoma of in the serum samples of EC patients. Significantly higher level of $\mathrm{Co}, \mathrm{Mg}, \mathrm{Hg}, \mathrm{As}, \mathrm{Cd}$ and $\mathrm{Cr}$ in the serum was exhibited by squamous cell carcinoma of EC patients. Nonetheless, considerably higher level of $\mathrm{K}$ was found in the serum of adenocarcinoma cancer patients from squamous cell carcinoma patients. Average Ca, Fe, Zn, Ag, Sr, Se and $\mathrm{Na}$ concentrations were found to be almost comparable in the serum of both types of esophagus carcinoma patients. Of note that toxic elemental levels were higher in both the types of EC patients, thereby indicating an association among elements and progression/development of malignancy. Comparative assessment of average elemental levels in the serum of various stages (I, II, III and IV) of EC patients is displayed in Fig. 2. At stage-I, Ca, Pb, Se and Sb showed elevated levels from mean levels at all other cancer stages. Excessive Pb suggests being carcinogenic and can exert oxidative stress via the generation of ROS and acting as cofactor in the oxidative damage of biological macromolecules (Balali-Mood et al. 2021). However, As, Ag and Mn levels exhibited significantly increase at stage II compared with other three stages. Arsenic is a systemic toxicant that affects almost all the organs of the body and induces various forms of health effects including cancer. In case of stage-III, $\mathrm{Ni}, \mathrm{Cd}$, and Co showed considerable higher mean levels as compared other stages. At present, elements such as $\mathrm{Co}, \mathrm{Cd}$ and $\mathrm{Ni}$ are recognized as carcinogenic substances and have been intensively investigated in recent years (Das et al. 2018; Xu et al. 2017). All these metals produce ROS via oxidative stress when their intake exceeds certain levels (Balali-Mood et al. 2021). Oxidative damage of biological macromolecules is associated with the overproduction of ROS which in turn development of diseases such as carcinoma (Rahman and Singh 2019). At stage IV of EC, average $\mathrm{Cu}, \mathrm{Cr}$, Sr and $\mathrm{Hg}$ contents were elevated when compared to the initial stages of EC patients. Multiple reports support the concept that $\mathrm{Cr}$, $\mathrm{Cu}$ and $\mathrm{Hg}$ have been recognized for the carcinogenic properties and involved in damage of DNA, changing of sulphydryl homeostasis and lipid peroxidation (Wallace and Djordevic 2020). Stimulate cell proliferation, inhibit apoptosis and DNA repair and promote carcinoma resulting from these toxicants (Lin et al. 2017). The elements such as $\mathrm{Cu}, \mathrm{Cr}, \mathrm{Sr}, \mathrm{Co}, \mathrm{Cd}, \mathrm{Ni}$ and $\mathrm{Hg}$ exhibited considerable decline in the average levels moving from initial stages I/II to advance stages III/ IV. However, Fe, Na, K and Mg revealed no considerable differences in their mean levels in the serum of EC patients as shown by all stages (Fig 4). Multivariate analysis The principal component analysis (PCA) of elemental levels in the serum samples of esophagus carcinoma patients and controls, extracted by varimax-normalized rotation on the data set is portrayed in Table 5. In patients, seven PCs of the elements with eigen values > 1 were produced, commutatively unveiling more than seventy five percent of the total variance of data. The corresponding cluster analysis (CA) based on Ward's method is given in Fig. 3. In the serum of EC patients, PC1 was dominantly contributed by $\mathrm{Cr}$, As, \& Sr and PC2 was majorly included for Fe and Pb supported by similar strong clusters in CA. These PCs were originated by anthropogenic sources and fossil fuels. Similarly, PC3 revealed higher loadings for Ag, Li and K which were duly supported by CA. The results of Table 5 showed that PC 4 was contained highest loadings of Se, Mn, Na and Mg. Further, PC4 shared common clusters in CA as given in Fig. 3. These two PCs were mainly contributed by internal body metabolism and associated with nutritious habits of the 
subjects. PC 5 consisted of $\mathrm{Cd}, \mathrm{Zn}$ and Ni which were believed to be controlled by environmental pollution and well supported by a shared cluster in CA. Cluster of metals ( $\mathrm{Cd}$ and Ni, carcinogenic agents) with anticarcionogenic metal ( $\mathrm{Zn}$ ) is an example of interference of toxic metals with essential metal (Mahmood et al. 2021; Qayyum et al. 2020). Finally, PC6 and PC7 exhibited maximum loadings for Cu, Co, \& Ca and Hg \& Sb respectively, which shared joint clusters in CA. These elements were mainly attributable to anthropogenic sources and nutritional habits. In case of controls, seven PCs of the elements were obtained with eigen values more than 1 , commutatively explaining more than $74 \%$ of the total variance of data. The corresponding CA in the form of dendrogram is showed in Fig. 4. PC1 with maximum variance of the data revealed highest loadings for $\mathrm{Co}$ and $\mathrm{Mn}$. PC2 revealed highest loadings for $\mathrm{Cr}$ and $\mathrm{Cu}$, well supported by a shared cluster in CA. These elements were traced to originate mostly from anthropogenic pollutants in the controls. PC3 exhibited maximum loadings for Ca, $\mathrm{As}, \mathrm{Pb}$ and $\mathrm{Fe}$, while the major metals of maximum loadings of PC4 included $\mathrm{Sr}, \mathrm{Mg}$ and $\mathrm{Na}$. Both the PCs revealed strong clusters for these elements and explaining mixed sources of these elements, such as nutritive habits, environmental exposure, and anthropogenic activities. In addition, high loadings of Sb, Se and Ni were detected in PC 5, which also exhibited a strong cluster in CA. Further, PC6 revealed maximum loadings of Zn and K in the serum of controls, whereas last PC indicated significant loadings for $\mathrm{Cd}, \mathrm{Ag}$, Li and $\mathrm{Hg}$ (Table 5). Both these PCs were mainly related with the internal body metabolism and anthropogenic emissions in the environment. It is worth to mention that in the case of healthy donors, the toxic elements were not primarily linked with the essential elements as was the case in the cancerous patients thus signifying a disproportion between the elements in esophagus carcinoma patients. Overall, PCA and CA exhibited significantly diverse apportionment of the essential/toxic elemental levels in the serum of esophagus carcinoma patients and healthy donors which might be illustrate to the imbalances of elements in the cancerous patients. To our knowledge, this is the first kind of study to explore the serum levels of essential/toxic elemental levels in Pakistani patients with EC as compared to controls. Essential and toxic elements were measured in the serum at various types and stages of EC, which have received little attention before. The limitations of the study were small sample size, lack of exposure assessment, and exposure intensity of specific occupation-related elements was not determined. Finally, the contamination of toxic elements has become a severe problem in onset/progression of EC risk. Consequently, further studies are required to explicate how/what metal contribute to the development of malignancy in esophagus.able 2. Majority of EC patients were of $\sim 52$ years old and healthy controls were $\sim 49$ years old on average basis. Among the selected subjects, $59 \%$ of patients were used tobacco in the form of cigarette, while $55 \%$ were cigarette smokers in the control group. Similarly, $48 \%$ and $58 \%$ of EC patients and healthy donors were from urban areas while $52 \%$ and $42 \%$ were belonged to rural areas, respectively. More than fifty percent of the patients and controls were vegetarian in their diets, while $49 \%$ of the controls and $46 \%$ of EC patients were non vegetarian in their food habit. Females (53\% of patients and $52 \%$ of controls) were greater than males ( $47 \%$ of patients and $48 \%$ of controls) as shown in demographic Table 1 . Both types of EC were diagnosed in patients from whom $56 \%$ were suffering from adenocarcinoma while $44 \%$ of patients were suffering from squamous cell carcinoma. Patients were also diagnosed at various stages of EC including $20 \%$ of the patients were identified at 1 st stage (stage-I), $30 \%$ at 2 nd stage (stage-II), $28 \%$ at 3 rd stage (stage-III) and $22 \%$ at 4 th stage (stage-IV) (Table 2). All EC patients were newly diagnosed and were not under previous medications. Serum CEA levels were measured in EC patients with mean value 861.7 nano gram per milliliter (range, 218.5-4359). The cutoff value for CEA in the serum was set as $<7 \mathrm{ng} / \mathrm{mL} \mathrm{provided}$ by the manufacturer company.

\section{Body mass index and esophagus cancer}

The body mass index (BMI) is the most commonly used measure of overweight and obesity. A high BMI has long been identified as a significant risk factor for many types of cancers including carcinoma of esophagus (Arnal et al. 2015). It is related to a higher incidence of gastroesophageal reflux which is strongly associated to the risk for Barrett esophagus (a metaplastic precursor state for adenocarcinomas) and EC (Turati et al., 2013). The risk of EC rises consistently with increasing BMI. Further, a raised BMI is a risk factor for development of EAC, while a reduce BMI is a risk factor for development of ESCC (Lindkvist et al. 2014). The mean value of body mass index (BMI) $(23.98 \mathrm{~kg} / \mathrm{m} 2$ (range, $21.57-24.91)$ ) was considerably higher in the EC patients than the controls (18.05 $\mathrm{kg} / \mathrm{m} 2$ (range 16.87-20.61)) as observed in the present study (Table 2). A number of studies have been conducted to explore the effects of BMI on the prognosis of EC patients (Gu et al. 2019). Nonetheless, the relationship between BMI and prognosis remains inconclusive and require further elucidation. Some observational studies advocated that BMI did not influence the survival of esophagus carcinoma patients. Others have advocated that a high BMI is an independent prognostic factor for the carcinoma of esophagus (Gu et al. 2019).

Accumulation of adipose tissue enhances the levels of endogenous hormones, including sex steroids, insulin, insulin growth factor-1, increasing cell proliferation, impairing apoptosis, consequently favoring preneoplastic and neoplastic cell growth. Although the true pathophysiology underlying this linkage remains unclear, however, obesity can lead to, facilitating gastroesophageal reflux and esophagitis, metabolic disturbances, such as increased levels of proinflammatory cytokines and adipokines, which may increase risk of carcinoma (Chen et al. 2012).

\section{Distribution of the elemental levels in the serum of esophagus cancer patients and controls}

The distribution of selected essential and toxic elemental levels $(\mu \mathrm{g} / \mathrm{g}$, wet weight) as basic statistical parameters in the serum of EC patients ( $\mathrm{n}=378)$ and controls $(n=353)$ are summarized in Table 3. Minimum and maximum levels were depicting that selected elements mostly pointed out wide range of their concentrations. For esophagus carcinoma patients, comparatively elevated average levels were obtained for $\mathrm{Na}$ ( $\mathrm{mean}, 244.7 \mu \mathrm{g} / \mathrm{g}, \mathrm{range}, 204.8-354.8 \mu \mathrm{g} / \mathrm{g}$ ),

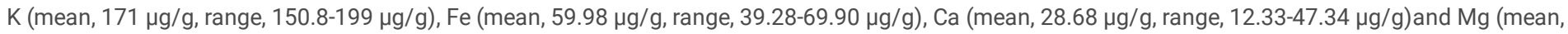
$15.17 \mu \mathrm{g} / \mathrm{g}$, range, $10.18-23.62 \mu \mathrm{g} / \mathrm{g}$ ) followed by, moderately lower levels of Zn (mean, 3.616 $\mu \mathrm{g} / \mathrm{g}$, range, 0.333-6.588 $\mu \mathrm{g} / \mathrm{g}$ ), Co (mean, $2.407 \mu \mathrm{g} / \mathrm{g}$, range,

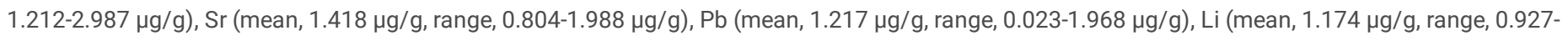
$2.083 \mu \mathrm{g} / \mathrm{g}$ ) and Se (mean, $1.027 \mu \mathrm{g} / \mathrm{g}$, range, 0.322-1.985 $\mu \mathrm{g} / \mathrm{g})$. However, average concentrations of Sb (mean, 0.970 $\mu \mathrm{g} / \mathrm{g}$, range, 0.167-1.642 $\mu \mathrm{g} / \mathrm{g}), \mathrm{Cu}$ (mean, $0.933 \mu \mathrm{g} / \mathrm{g}$, range, 0.025-1.821 $\mu \mathrm{g} / \mathrm{g}$ ), Mn (mean, 0.819 $\mu \mathrm{g} / \mathrm{g}$, range, 0.050-1.962 $\mu \mathrm{g} / \mathrm{g}$ ), Ni (mean, 0.539 $\mu \mathrm{g} / \mathrm{g}$, range, 0.006-5.299 $\mu \mathrm{g} / \mathrm{g}$ ), Cr (mean, $0.444 \mu \mathrm{g} / \mathrm{g}$, range, 0.004-2.101 $\mu \mathrm{g} / \mathrm{g}$ ), Ag (mean, $0.325 \mu \mathrm{g} / \mathrm{g}$, range, 0.105-0.987 $\mu \mathrm{g} / \mathrm{g}$ ), Cd (mean, 0.044 $\mu \mathrm{g} / \mathrm{g}$, range, $0.001-0.099 \mu \mathrm{g} / \mathrm{g}$ ), As 
(mean, $0.040 \mu \mathrm{g} / \mathrm{g}$, range, $0.011-0.100 \mu \mathrm{g} / \mathrm{g}$ ) and $\mathrm{Hg}$ (mean, $0.034 \mu \mathrm{g} / \mathrm{g}$, range, 0.010-0.099 $\mu \mathrm{g} / \mathrm{g}$ ) were evaluated at lowest concentrations in the serum of EC patients. Overall, average elemental levels exhibited following order in the serum of EC participants: $\mathrm{Na}>\mathrm{K}>\mathrm{Fe}>\mathrm{Ca}>\mathrm{Mg}>\mathrm{Zn}>\mathrm{Co}>\mathrm{Sr}>\mathrm{Pb}>\mathrm{Li}>\mathrm{Se}>\mathrm{Sb}>$ $\mathrm{Cu}>\mathrm{Mn}>\mathrm{Ni}>\mathrm{Cr}>\mathrm{Ag}>\mathrm{Cd}>\mathrm{As}>\mathrm{Hg}$. High values of $\mathrm{SD}$ and $\mathrm{SE}$ as well as unlike mean and median concentrations values of measured elements illustrated that majority of the elements showed unsystematic distribution. In terms of large SD and SE values, maximum dispersion were revealed by Na, K, Ca, Fe and $\mathrm{Mg}$; therefore, these elements were randomly distributed in the serum of EC patients which revealed non-Gaussian distribution pattern. Some of the elements ( $\mathrm{Cd}, \mathrm{As}, \mathrm{Ag}, \mathrm{Sr}$ and $\mathrm{Hg}$ ) depicted somewhat normal distribution pattern as evidenced by lower SD and SE values which exhibited Gaussian distribution. Elements like $\mathrm{Ni}, \mathrm{Li}, \mathrm{Cr}, \mathrm{Ag}, \mathrm{Hg}$ and $\mathrm{K}$ showed asymmetrical distribution as shown by large kurtosis and skewness values, while the rest of the elements exhibited relatively symmetrical distribution in the serum of EC patients (Table 3).

In the case of controls (Table 3), on the average, elemental concentrations were found dominant for Na (mean, $220.8 \mu \mathrm{g} / \mathrm{g}, \mathrm{range}, 104.4-277.1 \mu \mathrm{g} / \mathrm{g}$ ), followed by, $\mathrm{K}$ (mean, $199.4 \mu \mathrm{g} / \mathrm{g}$, range, 101.8-267.4 $\mu \mathrm{g} / \mathrm{g}$ ), Fe (mean, $91.22 \mu \mathrm{g} / \mathrm{g}$, range, 70.51-99.52 $\mu \mathrm{g} / \mathrm{g}$ ), Ca (mean, $42.84 \mu \mathrm{g} / \mathrm{g}$, range, $27.48-59.18 \mu \mathrm{g} / \mathrm{g}$ ), and Mg (mean, $18.07 \mu \mathrm{g} / \mathrm{g}$, range, 6.240-27.17 $\mu \mathrm{g} / \mathrm{g}$ ). However, relatively lower average levels were recorded for Zn (mean, 5.883 $\mu \mathrm{g} / \mathrm{g}$, range, $3.441-7.769 \mu \mathrm{g} / \mathrm{g}$ ), Co (mean, $3.408 \mu \mathrm{g} / \mathrm{g}$, range, 2.525-3.956 $\mathrm{gg} / \mathrm{g}$ ), Se (mean, $1.979 \mu \mathrm{g} / \mathrm{g}$, range, 1.064-3.921 $\mu \mathrm{g} / \mathrm{g}$ ), Sr (mean, $1.856 \mu \mathrm{g} / \mathrm{g}$, range, $1.096-2.438 \mu \mathrm{g} / \mathrm{g}$ ), Li (mean, 1.791 $\mu \mathrm{g} / \mathrm{g}$, range, 0.976-3.836 $\mu \mathrm{g} / \mathrm{g}), \mathrm{Mn}$ (mean, $1.339 \mu \mathrm{g} / \mathrm{g}$, range, 0.049-1.882 $\mu \mathrm{g} / \mathrm{g}$ ) and Sb (mean, $1.213 \mu \mathrm{g} / \mathrm{g}$, range, 0.128-3.813 $\mu \mathrm{g} / \mathrm{g}), \mathrm{Cu}(\mathrm{mean}, 0.603 \mu \mathrm{g} / \mathrm{g}$, range, 0.034-0.965 $\mu \mathrm{g} / \mathrm{g}$ ), $\mathrm{Pb}$ (mean, $0.515 \mu \mathrm{g} / \mathrm{g}$, range, 0.003-0.995 $\mu \mathrm{g} / \mathrm{g}), \mathrm{Ni}$ (mean, $0.295 \mu \mathrm{g} / \mathrm{g}$, range, 0.045-0.817 $\mu \mathrm{g} / \mathrm{g}), \mathrm{Ag}(\mathrm{mean}, 0.275 \mu \mathrm{g} / \mathrm{g}, \mathrm{range}, 0.011$ -

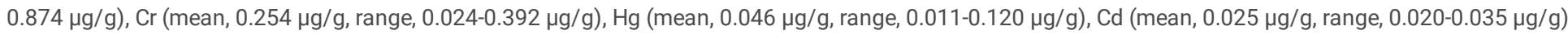
and As (mean, $0.022 \mu \mathrm{g} / \mathrm{g}$, range, $0.010-0.089 \mu \mathrm{g} / \mathrm{g}$ ) were found lowest levels in the serum of controls. On the mean scale, the decreasing trend of elemental levels in the serum of controls revealed following order: $\mathrm{Na}>\mathrm{K}>\mathrm{Fe}>\mathrm{Ca}>\mathrm{Mg}>\mathrm{Zn}>\mathrm{Co}>\mathrm{Se}>\mathrm{Sr}>\mathrm{Li}>\mathrm{Mn}>\mathrm{Sb}>\mathrm{Cu}>\mathrm{Pb}>\mathrm{Ni}>\mathrm{Ag}>\mathrm{Cr}>\mathrm{Hg}>\mathrm{Cd}>\mathrm{As}$. Among the selected elements, Fe, $\mathrm{Na}, \mathrm{Ca}$, Fe and Mg exhibited relatively higher dispersion as shown by higher SD and SE values. Other metals (Cd, Cr, As, $\mathrm{Hg}$, $\mathrm{Ag}$ and $\mathrm{Ni}$ ) noted somewhat normal distribution pattern manifested by relatively small SD and SE values. Increased skewness and kurtosis values for Se, Mn, $\mathrm{As}, \mathrm{Cr}$, and $\mathrm{Cu}$ supported asymmetrical distribution of these elements while modest skewness values for rest of the elements represented moderately symmetrical distribution in the serum of controls (Table 3).

\section{Comparison of the essential/toxic elemental levels in the serum of esophagus cancer patients and controls}

A systematic and detailed comparison (two sample $t$-test) of the average elemental levels measured in the serum of the patients and controls manifested that mean $\mathrm{Cu}, \mathrm{Ni}, \mathrm{Cr}, \mathrm{Cd}, \mathrm{Pb}, \mathrm{As}$ and $\mathrm{Ag}$ concentrations were observed to be significantly increased in the serum of EC patients $(p<0.05)$, while mean levels of Fe, $\mathrm{Ca}, \mathrm{Zn}, \mathrm{Co}, \mathrm{Mg}$, Se, Li and Mn were observed to be moderately higher in serum of the controls $(p<0.05)$. However, statistically non-significant differences at $p<$ 0.05 were found for average concentrations of $\mathrm{Sb}, \mathrm{Se}, \mathrm{K}$ and $\mathrm{Sr}$ in the serum of the EC patients and healthy donors. Similarly, median concentrations of the toxic/essential elements were also compared by Wilcoxon rank sum test which exhibited statistically significant differences $(p<0.05)$ for $\mathrm{Cr}$, $\mathrm{Pb}$, $\mathrm{Ni}, \mathrm{Mn}, \mathrm{Co}$, $\mathrm{Fe}$ and $\mathrm{Cu}$ in the serum samples of two groups. The comparison between EC patients and controls revealed therefore a buildup of toxic elements ( $\mathrm{Cr}$, $\mathrm{Cd}$, $\mathrm{Pb}$, As and $\mathrm{Ni}$ ) and deficiency of the essential elements ( $\mathrm{Se}, \mathrm{Zn}, \mathrm{Fe}$ and $\mathrm{Ca}$ ) in case of the cancerous patients than the healthy donors. These elevated concentrations of toxic elements found in the EC patients are proven carcinogen and their higher levels can further promote the carcinogenesis (Yang et al. 2021; Xie et al. 2019; Kazi et al. 2015). Moreover, the deficiencies of essential elements (i.e., Fe, Zn and Se) are linked to poor immunity and excessive accumulation of the reactive oxygen species (ROS) which further deteriorate the health of the patients (Lin et al. 2019). Significant differences in the levels of various toxic/trace elements in the blood, hairs and tissues of the EC cancer patients compared with the healthy controls have been reported in some studies (Rahman and Singh 2019; Kazi et al. 2915). Thus foregoing discussion clearly depicted that the relative distribution of the elements in the serum of EC patients is considerably different when compared to controls, which also pointed out the particular role of the elements in the development of the carcinoma (Dar et al. 2008; Lin et al. 2017). For instance $C d$ is a carcinogenic agent and a fatally toxic pollutant (Balali-Mood et al. 2021). It mimics Zn's divalent chemical state, so it can interfere with the DNA Zn binding site (Rahman et al. 2019). Various studies disclosed that Cd inhibits repairing of DNA damage by causing hindrance in its principle steps (Lin et al. 2017). Cadmium is included in group 1 carcinogen, having strong association with cancer as its chronic and long term exposure could cause malignant tumors to different organs such as brain, bladder, head, neck, breast, kidney, liver, prostate, lung and esophagus cancers (Jiang et al. 2021). Chromium is a toxic to human health and is classified as group I carcinogen by IARC (Balali-Mood et al. 2021). Following Fenton chemistry, Cr also interacts with hydrogen peroxide, thus producing a wide variety of ROS such as superoxide, singlet oxygen and hydroxyl radicals (Balali-Mood et al. 2021). In this way, Cr induced oxidative stress which result in cell DNA damage and breaks of DNA strand along with the formation of unstable DNA protein cross-links as well as Cr-DNA adducts (Rahman et al. 2019). There are epidemiological evidences that $\mathrm{Cr}$ and its compounds are positively associated with various types of carcinomas including respiratory, lung and stomach cancers (IARC 2018). Exposure of As to cells and tissues modulates the signaling pathways that involved in adverse processes including enhances cell proliferation, differentiation, blocking physiological apoptosis and are linked to the development of carcinoma (IARC 2012; Nurchi et al. 2020). The IARC and Environmental Protection Agency of US has classified As as a class I human carcinogen (Balali-Mood et al. 2021). Moreover, As potentiates/stimulates angiogenesis, mutagenesis, cytotoxic, and clastogenesis of other carcinogens which in turn to promote cancer development (Xu et al. 2017). Several epidemiological studies have claimed that exposure to As has been strongly linked with carcinomas in human organs such as the kidney, bladder, lung, liver, prostate and especially the skin (Nurchi et al. 2020; Xu et al. 2017). Carcinogenesis of Cu has to be assumed to increase oxidative stress via its involvement in the activation of hydrogen peroxide and later on, to produce more ROS like hydroxyl radicals that damage cellular DNA, proteins and lipids (Xie et al. 2019; Yang et al. 2021). Multiple reports have been published on the aberrant levels of Cu in malignant tissues of tumor-bearing mice and cancerous patients (Xu et al. 2017). Higher levels of Cu have been found in the patients of breast, ovary, lung, and stomach cancers (Michalczyk and Cymbaluk-Ploska 2020). Some studies disclosed high concentration of $\mathrm{Cu}$ in the blood of EC patients in comparison to healthy controls (Ahmad et al. 2011) while some studies explored lower concentration of $\mathrm{Cu}$ in the tissue of carcinoma patients as compared to controls (Joshaghani et al. 2017). In a cohort study, Cu was found to increase the risk of ESCC, even found in the tissue segments of esophagus (Hashemian et al. 2015). Goyal and its coworkers reported high concentration of $\mathrm{Cu}$ in the serum of esophagus carcinoma patients in comparison to healthy controls (Goyal et al. 2006). Recent literature also found high 
concentration of $\mathrm{Cu}$ in the serum of esophagus malignant patients as comparison to healthy controls (Yang et al. 2021; Dar et al. 2008). Lead also produces

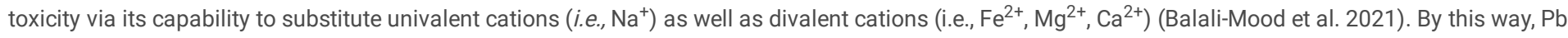
badly affects numerous basic natural functions of human body internal administration as well as cellular processes including release of neurotransmitters, enzyme regulation, ionic transportation, apoptosis, protein folding and maturation, cell adhesion and intra and intercellular signaling (Flora et al. 2012). In rodent cells, exposure to $\mathrm{Pb}$ induced gene mutations, sister chromatid exchanges, morphological transformations as well as to increase anchorage independence in diploid human fibroblasts (Wallace and Djordevic 2020). Experimental studies advocate that increased incidences of kidney cancer, lung, brain, and hematopoietic cancers, among rodents exposed to Pb (Kim et al. 2019; Balali-Mood et al. 2021). Exposure to Pb in battery manufacturing, smelting, and pigment production industries workers revealed high levels of $\mathrm{Pb}$ and its compounds and these studies claimed that there may be excess risks for lung and stomach cancers among these workers (Rahman and Singh 2019). In a case-control study, Ahmad et al. (2011) investigated the concentration of Pb in different specimens of EC patients was higher as compared to controls.

Nickel induced carcinogenicity, hepatotoxicity, nephrotoxicity, genotoxicity and neurotoxicity (Das et al. 2018). Other adverse effects of Ni are in lipid peroxidation and oxidative DNA damage (Lee et al. 2016). Nickel produces relatively low levels of ROS in cells which promotes oxidative DNA damage, inhibition of DNA repair activity and interferes in the activation of some transcription factors (Chen et al. 2017; Xu et al. 2017). The IARC has concluded that exposure to $\mathrm{Ni}$ is linked with an increased risk of lung and sinonasal cancers based on results from many studies (Das et al. 2018). Lee et al. (2016) inspected the content of $\mathrm{Ni}$ high and low rate EC prevalence areas and explored that concentration of Ni was higher in high rate areas than in low rate areas of EC. In a cohort study, workers of biggest Ni production enterprise in China were inspected and disclosed that deaths of these workers were due to different types of cancers including esophagus, lung, stomach and liver cancers (Ma et al. 2014; Lee et al. 2016). In addition, the means Ni was elevated in the serum of ESCC compared to controls as examined by Lin et al. (2017). Various studies advocated that Ca exerts shielding effect via promoting apoptosis, inhibiting cell cycle and also the generation of tumors (Shah et al. 2020). Protective effect of Ca was found in a study against ESCC and EAC in men (Park et al. 2009).

Hashemian et al. (2015) investigated the possible association of nutritional Ca with EAC cancer and found an inverse association with ESCC. Similar results were found in many others case-control studies (Jessri et al. 2011). However, there are some studies indicating not any relationship of Ca with EC (Lu et al. 2006; Hashemian et al. (2015). Animal studies also found out possible association of Ca with cancer. In a mice study, mice was fed with high Ca meal and observed inhibition of tumor formation, cell growth and metastasis as well (Ju et al. 2012). Higher dietary Ca intake is related to a lower risk of EC particularly in ESCC patients as claimed in Asian populations (Dawsey et al. 2014).

Iron overload is associated with increasing incidence rate and risk of carcinoma. Tumor patients may also have insufficient serum Fe (Khan et al. 2020). Moreover, Fe is involved in the initiation, growth, progression, and metastasis of cancer (Jung et al. 2019; Yang et al. 2021). Excess Fe plays an important role in tumor growth and tumor cell proliferation, and hence could be a cause of liver, gastrointestinal, esophagus, stomach and colorectum cancers (Lagergren et al. 2016). There are epidemiological proofs that give indication about the positive association of Fe with EC (Torti and Torti, 2011). Numerous studies showed excess usage of dietary haem Fe has potentially enhanced the risk of EAC in humans (Ward et al. 2012; Yang et al. 2021). It was also confirmed by a cohort study that excess of Fe is potentially carcinogenic and potentially enhances the risk EC (Ward et al. 2012). The serum Fe level of patients with EC was significantly higher compared with healthy controls (Yang et al. 2021). Selenium is a well-known electrometalloid and is mostly famous due to its anticancerous properties and chemopreventive effects (Keshavarzi et al., 2012). Selenium is serving as an essential component in selenoproteins and can reduce oxidative stress and limit DNA damage, both of which have been associated to carcinoma risk (Wei et al. 2004). Previous studies have demonstrated that Se deficiency/insufficiency may be linked to a variety of degenerative diseases, including cardiovascular disorders, immune dysfunctions and cancer (Keshavarzi et al. 2012; Wei et al. 2004). Level of high Se exposure Se may have different effects on specific types of carcinomas. It alleviates the risk of lung carcinoma, breast carcinoma, prostate carcinoma, gastric carcinoma and esophageal carcinoma (Cai et al. 2016). Selenium level in the serum of esophagus carcinoma patients was significantly lower than the healthy controls (Goyal et al. 2006; Yang et al. 2021). In Finland and the Netherlands, low Se concentrations were linked to an enhanced risk of rising ESCC and other carcinomas as shown in large cohort studies (Pritchett et al. 2017).

Zinc acts as a cofactor of superoxide dismutase for quenching of free radicals ultimately providing shield from cancer (Kazi et al. 2015). Various studies have explored that high content of Zn has an inverse association with different types of cancers (Fong et al. 2001; Joshaghani et al. 2017). Zinc deficiency promote mutagenesis, cell proliferation, differentiation, inhibit DNA synthesis and DNA repair as well as reduced antioxidant balance, having positive association with

EC (Dar et al. 2010; Prasad 2014). Hashemian et al. (2015) stated that Zn exert preventive effect against ESCC and have an inverse association with it. Several studies recorded that Zn level was found lower in EC patients than the controls (Yang et al. 2021; Dar et al. 2008). Goyal and his coworkers also disclosed lower level of $\mathrm{Zn}$ found in the serum of EC patients as compared to healthy controls (Goyal et al. 2006). Several retrospective and prospective human population-based surveys have underlined the role of $Z n$ deficiency as a risk factor for development of esophagus carcinoma (Nouri et al. 2008). A case control study was conducted in India, which evaluated that EC patients have considerably low mean concentration of $\mathrm{Zn}$ when compared to controls (Dar et al. 2008; Joshaghani et al. 2017). In other case-control study that was conducted in Pakistan, Zn value was recorded much lower in the different biological specimens of EC patients in comparison to healthy controls (Ahmad et al. 2011). On contrary, elevated level of Zn in the serum of EC patients compared to controls has been examined in some studies (Yang et al. 2021).

\section{Correlation study}

The data on element-to-element correlation in the serum of EC patients are explored in Table 4 (below the diagonal), wherein the bold $r$-values are significant at $p<0.05$. In case of EC patients, strong and significant positive correlations were noted between As-Sr ( $r=0.75), \mathrm{Cr}-\mathrm{Cd}(\mathrm{r}=0.73), \mathrm{Ag}-\mathrm{Li}(\mathrm{r}=0.71), \mathrm{Cu}-\mathrm{Cr}(\mathrm{r}=0.70), \mathrm{Cu}-$ $\mathrm{Ni}(\mathrm{r}=0.67), \mathrm{Ni}-\mathrm{Mn}(\mathrm{r}=0.66)$, Cr-As ( $r=0.65)$, Fe-Cd ( $r=0.65), \mathrm{Cr}-\mathrm{Pb}(\mathrm{r}=0.64), \mathrm{Zn}-\mathrm{Ni}(\mathrm{r}=0.61)$ and Ca-Cd $(r=0.60)$. In addition, some statistically significant relationships were detected among Ag-Sb ( $r=0.59)$, Sr-Na ( $r=0.59)$, Li-Ni ( $r=0.59)$, Ag-K ( $r=0.59)$, Li-Co ( $r=0.58), \mathrm{Ca}-\mathrm{Sr}(\mathrm{r}=0.57), \mathrm{Fe}-\mathrm{Co}(\mathrm{r}=0.57), \mathrm{Sb}-\mathrm{Co}(\mathrm{r}=0.57), \mathrm{Cu}-$ $\mathrm{Ag}(\mathrm{r}=0.57), \mathrm{Hg}-\mathrm{K}(\mathrm{r}=0.56), \mathrm{Hg}-\mathrm{Mn}(\mathrm{r}=0.56), \mathrm{Sr}-\mathrm{Se}(\mathrm{r}=0.56), \mathrm{Cu}-\mathrm{Na}(\mathrm{r}=0.55), \mathrm{Cu}-\mathrm{Hg}(\mathrm{r}=0.55), \mathrm{Zn}-\mathrm{Cd}(\mathrm{r}=0.54), \mathrm{As}-\mathrm{K}(\mathrm{r}=0.54), \mathrm{Mg}-\mathrm{Ni}(\mathrm{r}=0.53), \mathrm{Ag}-\mathrm{Se}(\mathrm{r}=0.53), \mathrm{Cd}-\mathrm{Pb}$ $(r=0.52)$, Zn-Co (r=0.52), Na-k ( $r=0.52)$ and Li-Mg ( $r=0.51)$. The significant positive correlations among the elements showed their probable communal

Page $10 / 23$ 
variations/sources in the serum samples of EC patients. Some of the elemental pairs such as Sb-Pb $(r=-0.57), \mathrm{As}-\mathrm{Cu}(r=-0.56), \mathrm{Mg}-\mathrm{Cu}(r=-0.55)$, Se-As $(r$ $=-0.54), \mathrm{Ni}-\mathrm{Fe}(\mathrm{r}=-0.52)$ and $\mathrm{Mg}-\mathrm{Na}(\mathrm{r}=-0.51)$ showed inverse relationships and opposing distributions in the serum of EC patients, which revealed the depletion or enrichment of specific elements at the cost of others. The correlation study pointed out mutual association between $\mathrm{Cu}, \mathrm{Mn}, \mathrm{Pb}, \mathrm{Li}, \mathrm{Ag}$ and $\mathrm{Ni}$ in the serum of the EC patients while one of the major electrolytes $(\mathrm{K})$ revealed contrasting variations with most of the elements thus illustrating the disproportional distribution of the elements in the serum of cancerous patients. Seemingly, positive relationships of toxic metals ( $\mathrm{Ni}, \mathrm{Cd}, \mathrm{As}, \mathrm{Hg}$, $\mathrm{Cu}$, and $\mathrm{Co}$ ) with essential elements ( $\mathrm{Fe}, \mathrm{Ca}, \mathrm{K}, \mathrm{Zn}$ and $\mathrm{Na}$ ) revealed a build-up of the toxic elements in serum of EC patients. Some epidemiological and clinical studies advocated the role of iron, lead, calcium and cadmium in the progression esophagus malignancy (Kim et al. 2019; Rahman and Singh 2019). Further these studies exhibited the critical role of some of these metals in the generation of oxidative stress via free radicals which later on resulted in development of neoplasm in esophagus (Balali-Mood et al. 2021).

In the case of controls, the correlation study exhibited significantly diverse mutual associations between the elements as shown in Table 4 (above the diagonal). Statistically, strong/significant correlations ( $p<0.05)$ were noted between Ni-Pb $(r=0.67), C a-S r(r=0.65), C d-A s(r=0.64), C r-A s(r=0.62), C d-S r$ $(r=0.61)$ and $\mathrm{Cu}-\mathrm{Co}(\mathrm{r}=0.60)$. Furthermore, statistically significant correlations were observed between $\mathrm{Fe}-\mathrm{Pb}(\mathrm{r}=0.68), \mathrm{Mn}-\mathrm{Hg}(\mathrm{r}=0.59), \mathrm{Mg}-\mathrm{Mn}(\mathrm{r}=0.58), \mathrm{Cr}-\mathrm{Pb}$ $(r=0.58)$, As-Ag ( $r=0.57)$, Ca-Na ( $r=0.57), \mathrm{Pb}-\mathrm{As}(\mathrm{r}=0.55), \mathrm{Ca}-\mathrm{Mg}(\mathrm{r}=0.55), \mathrm{Fe}-\mathrm{As}(\mathrm{r}=0.55), \mathrm{Ca}-\mathrm{Zn}(\mathrm{r}=0.54), \mathrm{Ag}-\mathrm{Mg}(\mathrm{r}=0.54), \mathrm{Fe}-\mathrm{Se}(\mathrm{r}=0.53), \mathrm{Cd}-\mathrm{Co}(\mathrm{r}=0.53), \mathrm{Cr}-\mathrm{Sb}$ $(r=0.52), \mathrm{Zn}-\mathrm{Ag}(\mathrm{r}=0.51), \mathrm{Pb}-\mathrm{Hg}(\mathrm{r}=0.51)$ and $\mathrm{Fe}-\mathrm{Cr}(\mathrm{r}=0.50)$. Some significant negative correlations were also shown among K-Na $(r=-0.59), \mathrm{As}-\mathrm{Cu}(r=-0.59)$, $\mathrm{Hg}-\mathrm{Ag}(\mathrm{r}=-0.57)$, Cu-Fe $(r=-0.55), \mathrm{K}-\mathrm{Ca}(r=-0.54)$, Li-Ni $(r=-0.53)$, Sb-Zn $(r=-0.50)$ and Co-Li $(r=-0.50)($ Table 4). Of note, unlike the patients, most of the essential elements ( $\mathrm{Zn}, \mathrm{Ca}, \mathrm{Na}, \mathrm{Fe}, \mathrm{K}$ and $\mathrm{Fe}$ ) showed significant mutual relationships in the serum of healthy donors. Overall, the correlation behavior of selected essential and toxic elements in the serum of EC was considerably divergent compared with controls, which may be attributed to the disproportions and imbalances of the elements in the cancerous patients.

\section{Comparison of the essential/toxic elemental levels based on demographic characteristics}

Mean essential/toxic elemental levels revealed in the serum samples of different demographic groups of EC patients and healthy donors/controls are compared by $t$-test (two-tailed, assuming unequal variance). Smoking-based comparison in the average levels of selected essential/toxic elements in the serum of esophagus carcinoma patients and healthy subject is displayed in the Fig. 1a which showed higher $\mathrm{Cu}, \mathrm{Ni}, \mathrm{Cr}, \mathrm{Pb}, \mathrm{Cd}, \mathrm{As}$ and $\mathrm{Ag}$ levels in smoker patients than the smoker controls. Mean values of $\mathrm{Sb}, \mathrm{Mn}, \mathrm{Co}, \mathrm{Mg}, \mathrm{K}, \mathrm{Se}, \mathrm{Zn}, \mathrm{Hg}, \mathrm{Fe}, \mathrm{Ca}$ and $\mathrm{Zn}$ were elevated in smoker controls than smoker patients. Nevertheless, average values of $\mathrm{Hg}, \mathrm{Se}, \mathrm{Zn}, \mathrm{K}, \mathrm{Sb}, \mathrm{Mn}, \mathrm{Fe}, \mathrm{Co}, \mathrm{Ca}$ and Se were recognized to be considerably higher in the serum of non-smoker controls than non-smoker patients. In the case of non-smoker patients, average levels of $\mathrm{Li}, \mathrm{Ag}, \mathrm{As}, \mathrm{Cd}, \mathrm{Cr}$, $\mathrm{Ni}$ and $\mathrm{Cu}$ were pointed out to be significantly elevated in the serum as compared to non-smoker controls as displayed in Fig. 1a. Cigarette smoking also influenced/enhanced risk of EC, no matter expressed as the frequency, duration/cumulative smoking amount (Li et al. 2014). Many components of tobacco contain carcinogens which may contribute to the pathogenesis of EC (Wang

et al. 2017). There is a 1.5-to four-fold increase in EC risk among smokers as claimed in some studies; however in other studies no association has been established (Yang et al. 2017).

Comparison of average levels of selected essential/toxic elements in the serum of the esophagus carcinoma patients and healthy donors depend on their abode is showed in the Fig. 1b. Comparative evaluation of the elements revealed approximately equivalent contributions of Zn, As, Sr, $\mathrm{Na}, \mathrm{K}$, Mg and Fe in the serum of urban and rural esophagus carcinoma patients. However, average $\mathrm{Cu}, \mathrm{Ni}$ and $\mathrm{Ag}$ contents depicted significantly higher contribution in the serum of urban patients than rural patients, while average concentrations of $\mathrm{Se}, \mathrm{Cr}$, Sb and $\mathrm{Cd}$ were found to be comparatively higher in the serum of rural patients than the urban patients. In case of healthy donors, relatively higher mean concentrations of $\mathrm{Ca}, \mathrm{Fe}, \mathrm{Zn}, \mathrm{Se}, \mathrm{K}, \mathrm{Co}, \mathrm{Mg}$, Mn and Sb were recorded in the serum of urban controls compared with the urban patients. Mean $\mathrm{Co}, \mathrm{K}, \mathrm{Se}, \mathrm{Hg}, \mathrm{Ag}, \mathrm{Zn}$, Fe and Ca were relatively elevated in the serum of rural healthy donors than rural patients as shown in Fig. Nonetheless, average concentrations of $\mathrm{Mn}, \mathrm{Mg}, \mathrm{Na}, \mathrm{Li}, \mathrm{Sr}$ and $\mathrm{Ni}$ were almost comparable in both urban and rural controls as shown in Fig.1b.

During recent years, food contaminations by chemicals such as toxic elements have become inevitable problems from the environment. Recent data supports that there is an association between some dietary components and risk of carcinogenic process in esophagus (Liu et al. 2017). However, the association is not yet clear. Similarly, the results of several epidemiological studies revealed that some dietary patterns are significantly associated with an increased risk of ESCC (Jessri et al. 2011). Use high starch food and low quantity of fresh fruits as well as vegetables have been linked to process of EC (Liu et al. 2017). Epidemiological investigations along different lines revealed adequate consumption of fruit and vegetable was significantly related with decreased risk of EC which could play a role in protecting against this malignancy (Jessri et al. 2011). Dietary-based (vegetarian and non vegetarian) comparison of the selected elements in the serum of the EC patients and controls is shown in Fig. 1c, revealed comparatively high mean level of $\mathrm{Cu}, \mathrm{Ni}$, $\mathrm{Ag}$ and $\mathrm{Li}$ in the vegetarian patients than the non-vegetarian counterparts which exposed elevated levels of $\mathrm{Mn}, \mathrm{Se}, \mathrm{Ca}, \mathrm{Cd}$ and $\mathrm{Cr}$ in their serum. Nevertheless, average concentrations of $\mathrm{Fe}, \mathrm{Zn}, \mathrm{Pb}, \mathrm{As}, \mathrm{Sr}, \mathrm{Hg}, \mathrm{Na}, \mathrm{K}$ and $\mathrm{Mg}$ were found to be comparable in both patient groups. In the case of healthy donors, mean elemental Co, Mn, Sb, Se, Zn, Fe and $\mathrm{Ca}$ contents were found to be higher in the serum of non-vegetarian controls as compared to non vegetarian patients. Similarly, average $\mathrm{Hg}$, Se, Ca, $\mathrm{K}$, Fe, $\mathrm{Mn}, \mathrm{Zn}$ and $\mathrm{Co}$ levels were maximum in the serum of vegetarian controls than vegetarian $\mathrm{EC}$ patients. Besides, average concentrations of $\mathrm{Cu}$, $\mathrm{Cd}$, $\mathrm{Pb}$, As, $\mathrm{Ni}$, $\mathrm{Cr}$, $\mathrm{Ag}$ and $\mathrm{Li}$ were found to be considerably elevated in the serum of vegetarian patients than non vegetarian controls as shown in Fig. 1c.

Carcinoma of esophagus continues to be a man dominant malignancy. Esophagus carcinoma is 2 to 3 times more common in males than females worldwide (Lin et al. 2017). Gender-based comparison as shown in Fig. $1 \mathrm{~d}$ revealed comparatively high average concentrations of $\mathrm{Cu}, \mathrm{Ni}$, $\mathrm{Cr}, \mathrm{Pb}$, and $\mathrm{Ag}$ in the serum of female patients than female controls. Whereas elemental $\mathrm{Zn}, \mathrm{Sd}, \mathrm{Hg}$, Se and $\mathrm{Sb}$ contents were higher in the serum of female controls. Average $\mathrm{Cu}$, $\mathrm{Ni}$, $\mathrm{Cr}$, $\mathrm{Cd}$, $\mathrm{Pb}, \mathrm{As}$ and $\mathrm{Sb}$ levels were found elevated in the serum of male EC patients when compared to male controls. Similarly, mean $\mathrm{Ca}$, Fe, Zn, Ag, $\mathrm{Hg}$, Se, $\mathrm{K}$ and Co 
contents revealed higher in the serum of male controls as compared to male patients. Nevertheless, mean levels of Mn, $\mathrm{Co}, \mathrm{Mg}, \mathrm{K}, \mathrm{Na}, \mathrm{Li}, \mathrm{Sr}$, Fe and Ca were exhibited to be nearly equivalent in both patient groups (Fig. 1d). Hence, discovery of a credible and strong causal association between trace elements and carcinoma of the esophagus may create a new frontier for the prevention and management of an established disease.

\section{Comparison of the elemental levels based on types and stages}

Comparative evaluation of the average toxic/essential elemental levels in the serum of both types (adenocarcinoma and squamous cell carcinoma) of the EC patients is displayed in Fig. 2. The patients suffered from adenocarcinoma showed relatively elevated levels of $\mathrm{Cu}, \mathrm{Ni}, \mathrm{Pb}$, $\mathrm{Li}, \mathrm{Sb}$ and $\mathrm{Mn}$ than squmaous cell carcinoma of in the serum samples of EC patients. Significantly higher level of Co, Mg, $\mathrm{Hg}, \mathrm{As}, \mathrm{Cd}$ and $\mathrm{Cr}$ in the serum was exhibited by squamous cell carcinoma of EC patients. Nonetheless, considerably higher level of $\mathrm{K}$ was found in the serum of adenocarcinoma cancer patients from squamous cell carcinoma patients. Average $\mathrm{Ca}, \mathrm{Fe}, \mathrm{Zn}, \mathrm{Ag}, \mathrm{Sr}$, Se and $\mathrm{Na}$ concentrations were found to be almost comparable in the serum of both types of esophagus carcinoma patients. Of note that toxic elemental levels were higher in both the types of EC patients, thereby indicating an association among elements and progression/development of malignancy.

Comparative assessment of average elemental levels in the serum of various stages (I, II, III and IV) of EC patients is displayed in Fig. 2. At stage-I, Ca, Pb, Se and $\mathrm{Sb}$ showed elevated levels from mean levels at all other cancer stages. Excessive $\mathrm{Pb}$ suggests being carcinogenic and can exert oxidative stress via the generation of ROS and acting as cofactor in the oxidative damage of biological macromolecules (Balali-Mood et al. 2021). However, As, Ag and Mn levels exhibited significantly increase at stage II compared with other three stages. Arsenic is a systemic toxicant that affects almost all the organs of the body and induces various forms of health effects including cancer. In case of stage-III, Ni, Cd, and Co showed considerable higher mean levels as compared other stages. At present, elements such as $\mathrm{Co}, \mathrm{Cd}$ and $\mathrm{Ni}$ are recognized as carcinogenic substances and have been intensively investigated in recent years (Das et al. 2018; Xu et al. 2017). All these metals produce ROS via oxidative stress when their intake exceeds certain levels (Balali-Mood et al. 2021). Oxidative damage of biological macromolecules is associated with the overproduction of ROS which in turn development of diseases such as carcinoma (Rahman and Singh 2019). At stage IV of EC, average $\mathrm{Cu}, \mathrm{Cr}$, Sr and $\mathrm{Hg}$ contents were elevated when compared to the initial stages of EC patients. Multiple reports support the concept that $\mathrm{Cr}$, $\mathrm{Cu}$ and $\mathrm{Hg}$ have been recognized for the carcinogenic properties and involved in damage of DNA, changing of sulphydryl homeostasis and lipid peroxidation (Wallace and Djordevic 2020). Stimulate cell proliferation, inhibit apoptosis and DNA repair and promote carcinoma resulting from these toxicants (Lin et al. 2017). The elements such as $\mathrm{Cu}, \mathrm{Cr}, \mathrm{Sr}, \mathrm{Co}, \mathrm{Cd}, \mathrm{Ni}$ and $\mathrm{Hg}$ exhibited considerable decline in the average levels moving from initial stages I/II to advance stages III/ IV. However, $\mathrm{Fe}, \mathrm{Na}, \mathrm{K}$ and $\mathrm{Mg}$ revealed no considerable differences in their mean levels in the serum of EC patients as shown by all stages (Fig 4).

\section{Multivariate analysis}

The principal component analysis (PCA) of elemental levels in the serum samples of esophagus carcinoma patients and controls, extracted by varimaxnormalized rotation on the data set is portrayed in Table 5. In patients, seven PCs of the elements with eigen values $>1$ were produced, commutatively unveiling more than seventy five percent of the total variance of data. The corresponding cluster analysis (CA) based on Ward's method is given in Fig. 3. In the serum of EC patients, PC1 was dominantly contributed by $\mathrm{Cr}$, As, \& Sr and PC2 was majorly included for Fe and Pb supported by similar strong clusters in CA. These PCs were originated by anthropogenic sources and fossil fuels. Similarly, PC3 revealed higher loadings for Ag, Li and K which were duly supported by CA. The results of Table 5 showed that PC 4 was contained highest loadings of Se, Mn, Na and Mg. Further, PC4 shared common clusters in CA as given in Fig. 3. These two PCs were mainly contributed by internal body metabolism and associated with nutritious habits of the subjects. PC 5 consisted of Cd, Zn and $\mathrm{Ni}$ which were believed to be controlled by environmental pollution and well supported by a shared cluster in CA. Cluster of metals (Cd and Ni, carcinogenic agents) with anticarcionogenic metal ( $\mathrm{Zn}$ ) is an example of interference of toxic metals with essential metal (Mahmood et al. 2021; Qayyum et al. 2020). Finally, PC6 and PC7 exhibited maximum loadings for $\mathrm{Cu}, \mathrm{Co}, \& \mathrm{Ca}$ and $\mathrm{Hg} \& \mathrm{Sb}$ respectively, which shared joint clusters in CA. These elements were mainly attributable to anthropogenic sources and nutritional habits.

In case of controls, seven PCs of the elements were obtained with eigen values more than 1, commutatively explaining more than $74 \%$ of the total variance of data. The corresponding CA in the form of dendrogram is showed in Fig. 4. PC1 with maximum variance of the data revealed highest loadings for Co and Mn. $\mathrm{PC} 2$ revealed highest loadings for $\mathrm{Cr}$ and $\mathrm{Cu}$, well supported by a shared cluster in $\mathrm{CA}$. These elements were traced to originate mostly from anthropogenic pollutants in the controls. PC3 exhibited maximum loadings for $\mathrm{Ca}, \mathrm{As}, \mathrm{Pb}$ and Fe, while the major metals of maximum loadings of PC4 included Sr, Mg and $\mathrm{Na}$. Both the PCs revealed strong clusters for these elements and explaining mixed sources of these elements, such as nutritive habits, environmental exposure, and anthropogenic activities. In addition, high loadings of Sb, Se and Ni were detected in PC 5, which also exhibited a strong cluster in CA. Further, PC6 revealed maximum loadings of $\mathrm{Zn}$ and $\mathrm{K}$ in the serum of controls, whereas last PC indicated significant loadings for $\mathrm{Cd}$, Ag, $\mathrm{Li}$ and $\mathrm{Hg}$ (Table 5 ). Both these PCs were mainly related with the internal body metabolism and anthropogenic emissions in the environment. It is worth to mention that in the case of healthy donors, the toxic elements were not primarily linked with the essential elements as was the case in the cancerous patients thus signifying a disproportion between the elements in esophagus carcinoma patients. Overall, PCA and CA exhibited significantly diverse apportionment of the essential/toxic elemental levels in the serum of esophagus carcinoma patients and healthy donors which might be illustrate to the imbalances of elements in the cancerous patients.

To our knowledge, this is the first kind of study to explore the serum levels of essential/toxic elemental levels in Pakistani patients with EC as compared to controls. Essential and toxic elements were measured in the serum at various types and stages of EC, which have received little attention before. The limitations of the study were small sample size, lack of exposure assessment, and exposure intensity of specific occupation-related elements was not 
determined. Finally, the contamination of toxic elements has become a severe problem in onset/progression of EC risk. Consequently, further studies are required to explicate how/what metal contribute to the development of malignancy in esophagus.

\section{Conclusions}

The analyses of elements have been carried out to identify potential differences of toxic/essential elemental concentrations among esophagus cancer patients and without EC in the serum. In this study, elemental $\mathrm{Cu}, \mathrm{Ni}, \mathrm{Cr}, \mathrm{Cd}, \mathrm{Pb}, \mathrm{As}$ and $\mathrm{Ag}$ concentrations showed significantly higher $(p<0.05)$ in the serum of esophagus cancer patients than controls, while mean concentration of $\mathrm{Li}, \mathrm{Se}, \mathrm{Fe}, \mathrm{Ca}, \mathrm{Zn}, \mathrm{Sr}$ and $\mathrm{Mn}$ were found to be higher in the healthy donors. The correlation study revealed considerable associations among the essential and toxic elements in $\mathrm{EC}$ patients. In adenocarcinoma, elevated levels of $\mathrm{Cu}$, $\mathrm{Ni}$, $\mathrm{Pb}$, $\mathrm{Li}, \mathrm{Sb}, \mathrm{K}$ and $\mathrm{Mn}$ were observed while $\mathrm{Co}, \mathrm{Mg}, \mathrm{Hg}, \mathrm{As}, \mathrm{Cd}$ and $\mathrm{Cr}$ were higher in the serum of squamous cell carcinoma of EC patients. Among clinical stages, $\mathrm{Ca}, \mathrm{Pb}, \mathrm{Se}$ and $\mathrm{Sb}$ showed elevated levels at stage-I whereas, As, Ag and Mn levels exhibited significantly increased at stage II compared with other stages. At stage III, the concentrations of $\mathrm{Ni}, \mathrm{Cd}$, and $\mathrm{Co}$ showed higher while $\mathrm{Hg}, \mathrm{Sr}, \mathrm{Cr}$ and Cu exhibited highest levels at stage-IV in the serum of EC patients. Most of the elements disclosed considerable disparities in their levels based on sex, smoking, adobe and dietary habits of the subjects. It was further explicated in terms of PCA and CA which revealed diverse apportionment of the elements in esophagus carcinoma patients and controls. Overall, disproportions in the elemental contents in cancerous patients when compared to controls demonstrated significant role of the essential and toxic elements in the onset/progression of the malignancy.

\section{Declarations}

\section{Acknowledgements}

The authors would like to thank the patients and clinicians of PINUM and Allied hospital Faisalabad that make this work possible. We are appreciative for the technical and financial support provided by Department of Chemistry, University of Education, Lahore, Pakistan to carry out the present investigations.

\section{Ethical approval}

All procedures followed were in accordance with the ethical standards of the responsible committee on human experimentation (institutional and national) and with the Helsinki Declaration of 1964 and its later amendments. Informed consent was obtained from all participants for being included in the study.

\section{Informed consent (Consent to Participate)}

Informed consent was obtained from all patients and controls for being included in the present research work. All the participants were agreed voluntary in the present study.

\section{Consent for publication}

All authors have read and approved the final submitted manuscript. We certify that this manuscript is original and not previously published in any form including on preprint servers, nor is it being considered elsewhere.

\section{Authors' contributions}

Qayyum MA and Farooq T performed the conception, preparation and writing. Sultan MH ensured sampling, experiment and the analysis of results. Qayyum MA and Muddassir K statistically analyze the data as well as the writing of the present article. Farooq Z and Irfan A contributed to the software, experiment and visualization. Muddassir $\mathrm{K}$ contributed in the review and editing as well.

\section{Funding}

The authors have no relevant financial or nonfinancial interests to disclose.

\section{Data availability}

Data available on request due to restrictions e.g., privacy or ethical.

\section{Conflict of interest}

Authors declare no conflict of interest.

\section{References}


1. Abnet CC, Arnold M, Wei WQ (2018) Epidemiology of esophageal squamous cell carcinoma. Gastroenterology 154(2):360373. https://doi.org/10.1053/j.gastro.2017.08.023

2. Ahmad B, Ghani H, Azam S, Bashir S, Begum N (2011) The status of trace elements in lymphoma and esophageal cancer patients: a case study. Afr J Biotechnol 10(84):19645-19649. https://doi.org/10.5897/AJB11.1450

3. Arnal MJD, Arenas AF, Arbeloa AL (2015) Esophageal cancer: Risk factors, screening and endoscopic treatment in Western and Eastern countries. World J Gastroenterol 21(26): 7933-7943. https://doi.org/10.3748/wjg.v21.i26.7933

4. Asghar MS, Khan NA, Kazmi SJ, Hassan M, Rasheed U, Jawed R, Yaseen R, Naqvi SAA (2021) Clinical, epidemiological, and diagnostic characteristics of esophageal carcinoma amongst the population of urban Sindh: a tertiary care hospital experience of Karachi, Pakistan. Ann Saudi Med 41(2): 91100. https://doi.org/10.5144/0256-4947.2021.91

5. Bagaria B, Bagaria A, Singh M, Sharma R (2015) Diagnostic sensitivity of serum carcinoembryonic antigen, carbohydrate antigen 19-9, alpha-fetoprotein, and beta-human chorionic gonadotropin in esophageal carcinoma (receiver operating characteristic curve analysis). Clin Cancer Investig J 4:312-317. https://doi.org/10.4103/2278-0513.154279

6. Balali-Mood M, Naseri K, Tahergorabi Z, Khazdair MR, Sadeghi M (2021) Toxic mechanisms of five heavy metals: mercury, lead, chromium, cadmium, and arsenic. Front Pharmacol 12: 643972. https://doi.org/10.3389/fphar.2021.643972

7. Bray F, Ferlay J, Soerjomataram I, Siegel RL, Torre LA, Jemal A (2018) Global cancer statistics 2018: GLOBOCAN estimates of incidence and mortality worldwide for 36 cancers in 185 countries. CA Cancer J Clin 68:394-424. https://doi.org/10.3322/caac.21492

8. Cai X, Wang C, Yu W, Fan W, Wang S, Shen N, Wu P, Li X, Wang F (2016) Selenium exposure and cancer risk: an updated meta-analysis and metaregression. Sci Rep 6:19213. https://doi.org/10.1038/srep19213

9. Chen Q, Zhuang H, Liu Y (2012) The association between obesity factor and esophageal cancer. J Gastrointest Oncol 3(3):226231. https://doi.org/10.3978/j.issn.2078-6891.2012.026

10. Chen QY, Brocato J, Laulicht F, Costa M, (2017) Mechanisms of nickel carcinogenesis. In: Mudipalli A., Zelikoff J.T., editors. Essential and Non-Essential metals. Molecular and Integrative Toxicology. Springer International Publishing AG; New York, NY, USA. pp. 181-197.

11. Dar NA, Mir MM, Salam I, Malik MA, Gulzar GM, Yatoo GN, Ahmed A, Shah A (2008) Association between copper excess, zinc deficiency, and TP53 mutations in esophageal squamous cell carcinoma from Kashmir Valley, India-a high risk area. Nutr Cancer 60:585591. https://doi.org/10.1080/01635580802290231.

12. Das KK, Reddy RC, Bagoji IB, Das S, Bagali S, Mullur L, Khodnapur JP, Biradar MS (2018) Primary concept of nickel toxicity-an overview. J Basic Clin. Physiol Pharmacol 30: 141-152. https://doi.org/10.1515/jbcpp-2017-0171.

13. Flora G, Gupta D, Tiwari A (2012) Toxicity of lead: A review with recent updates, Interdiscip Toxicol. 5(2): 47-58. https://doi.org/10.2478/v10102-012$0009-2$

14. Fong LY, Nguyen VT, Farber JL (2001) Esophageal cancer prevention in zinc deficient rats: rapid induction of apoptosis by replenishing zinc. J Natl Cancer Inst 93(20): 1525-1533. https://doi.org/10.1093/jnci/93.20.1525

15. Goyal MM, Kalwar AK, Vyas RK, Bhati A (2006) Study of serum zinc, selenium and copper levels in carcinoma of esophagus patients. Indian J Clin Biochem 21: 208-210. https://doi.org/10.1007/BF02913100

16. Gu WS, Fang WZ, Liu CY, Pan KY, Ding R, Li XH, Duan CH (2019). Prognostic significance of combined pretreatment body mass index (BMI) and BMI loss in patients with esophageal cancer. Cancer Manag Res 11:3029-3041. https://doi.org/10.2147/CMAR.S197820

17. Hashemian M, Poustchi H, Abnet CC, Boffetta P, Dawsey SM, Brennan PJ, Pharoah P, Etemadi A, Kamangar F, Sharafkhah M, Hekmatdoost A, Malekzadeh R (2015) Dietary intake of minerals and risk of esophageal squamous cell carcinoma: Results from the Golestan cohort study. Am J Clin Nutr 102:102108. https://doi.org/10.3945/ajcn.115.107847

18. Huang J, Koulaouzidis A, Marlicz W, Lok V, Chu C, Ngai CH, Zhang L, Chen P, Wang S, Yuan J, Lao XQ, Tse SLA, Xu W, Zheng ZJ, Xie SH, Wong MCS (2021) Global burden, risk factors, and trends of esophageal cancer: an analysis of cancer registries from 48 countries. Cancers 13:141. https://doi.org/ 10.3390/cancers 13010141

19. IARC (2012) IARC Working Group on the Evaluation of Carcinogenic Risks to Humans. Arsenic, metals, fibres, and dusts. 2012;100(PT C):11. IARC Monogr. Eval. Carcinog. Risks Humans 2012, 100, 11.

20. IARC (2018) Chromium (VI) compounds; World Health Organization: Lyon, France, Volume 1-42.

21. Jain S, Dhingra S (2017) Pathology of esophageal cancer and Barrett's esophagus, Ann Cardiothorac Surg 6(2):99109. https://doi.org/10.21037/acs.2017.03.06.

22. Jessri M, Rashidkhani B, Hajizadeh B, Jessri M, Gotay C (2011) Macronutrients, vitamins and minerals intake and risk of esophageal squamous cell carcinoma: a case-control study in Iran. Nutr J 10:137. https://doi.org/10.1186/1475-2891-10-137

23. Jiang A, Gong L, Ding H, Wang M (2021) Cancer mortality and long-term environmental exposure of cadmium in contaminated community based on a third retrospective cause of death investigation of residents living in the Guangdong province from 2004 to 2005, Bio Trace Elem Res. https://doi.org/10.1007/s12011-021-02599-0

24. Jolliffe IT (2002) Principal component analysis. $2^{\text {nd }}$ Edn. Springer, New York

25. Jolliffe IT, Cadima J (2016) Principal component analysis: a review and recent developments. Phil. Trans. R. Soc. A 374:20150202. http://dx.doi.org/10.1098/rsta.2015.0202

26. Joshaghani HR, Mirkarimi HS, Besharat S, Roshandel GR, Sanaei O, Nejabat M (2017) Comparison of the serum levels of trace elements in areas with high or low rate of esophageal cancer. Middle East J Dig Dis 9:81-85. https://doi.org/10.15171/mejdd.2017.55

Page $14 / 23$ 
27. Ju J, Kwak Y, Hao X, Yang CS (2012) Inhibitory effects of calcium against intestinal cancer in human colon cancer cells and ApcMin/+ mice. Nutr Res Pract 6(5):396-404. https://doi.org/10.4162/nrp.2012.6.5.396

28. Jung M, Mertens $C$, Tomat E, Brune B (2019) Iron as a central player and promising target in cancer progression. Int J Mol Sci 20:273; https://doi.org/10.3390/ijms20020273

29. Kazi TG, Wadhwa SK, Afridi HI, Talpur FN, Tuzen M, Baig JA (2015) Comparison of essential and toxic elements in esophagus, lung, mouth and urinary bladder male cancer patients with related to controls, Environ Sci Pollut Res Int 22:7705-7715. https://doi.org/10.1007/s11356-014-3988-z

30. Keshavarzi B, Moore F, Najmeddin A, Rahmani F (2012) The role of selenium and selected trace elements in the etiology of esophageal cancer in high risk Golestan province of Iran. Sci Total Environ 433:89-97. https://doi.org/10.1016/j.scitotenv.2012.04.033.

31. Khan A, Singh P, Srivastava A (2020) Iron: Key player in cancer and cell cycle?. J Trace Elem Med Bio 62: 126582. https://doi.org/10.1016/j.jtemb.2020.126582.

32. Kim JJ, Kim YS, Kumar V (2019) Heavy metal toxicity: An update of chelating therapeutic strategies. J Trace Elem Med Biol 54:226231. https://doi.org/10.1016/j.jtemb.2019.05.003

33. Lagergren K, Wahlin K, Mattsson F, Alderson D, Lagergren J (2016) Haemochromatosis and gastrointestinal cancer, Int J Cancer 139(8):17401743. https://doi.org/10.1002/ijc.30229

34. Lee CP, Lee YH, Lian IB, Su CC (2016). Increased prevalence of esophageal cancer in areas with high levels of nickel in farm soils. J Cancer 7:1724-1730. https://doi.org/10.7150/jca.15441

35. Li LF, Chan R.L.Y, Lu L, Shen J, Zhang L, Wu WKK, Wang L, Hu T, Li MX, Cho CH (2014) Cigarette smoking and gastrointestinal diseases: The causal relationship and underlying molecular mechanisms (Review), Int J Mol Med 34: 372-380. https://doi.org/10.3892/ijmm.2014.1786

36. Lin T, Liu T, Lin Y, Zhang C, Yan L,Chen X, He Z, Wang J (2017) Serum levels of chemical elements in esophageal squamous cell carcinoma in Anyang, China: a case-control study based on machine learning methods. BMJ Open 7:e015443. https://doi.org/10.1136/ bmjopen-2016-015443

37. Lindkvist B, Johansen D, Stocks T, Concin H, Bjorge T, Almquist M, Häggström C, Engeland A, Hallmans G, Nagel G, Jonsson H, Selmer R, Ulmer H, Tretli S, Stattin P, Manjer J (2014) Metabolic risk factors for esophageal squamous cell carcinoma and adenocarcinoma: a prospective study of 580000 subjects within the Me-Can project. BMC Cancer 14:103. https://doi.org/10.1186/1471-2407-14-103.

38. Liu X, Wang X, Lin S, Lao X, Zao J, Song Q, Su X, Yu ITS (2017) Dietary patterns and the risk of esophageal squamous cell carcinoma: a population-based case-control study in a rural population. Clin Nutr 36: 260-266. http://dx.doi.org/10.1016/j.clnu.2015.11.009

39. Lu H, Cai L, Mu LN, Lu QY, Zhao J, Cui Y, Sul JH, Zhou XF, Ding BG, Elashoff RM, Marshall J, Yu SZ, Jiang QW, Zhang ZF (2006) Dietary mineral and trace element intake and squamous cell carcinoma of the esophagus in a Chinese population. Nutr Cancer 55:63-

70. https://doi.org/10.1207/s15327914nc5501_8

40. Ma L, Bai YN, Pu HQ, He J, Bassig BA, Min D,Wei ZY, Zhang TZ, Cheng N (2014) A retrospective cohort mortality study in jinchang, the largest nickel production enterprise in China. Biomed Environ Sci 27(7): 567-571. https://doi.org/10.3967/bes2014.088.

41. Mahmood MHR, Qayyum M, Yaseen F, Farooq T, Farooq Z, Yaseen M, Irfan A, Muddassir K, Zafar MN, Qamar MT, Abbasi AM, Liu HY (2021) Multivariate investigation of toxic and essential metals in the serum from various types-and-stages of colorectal cancer patients, Bio Trace Elem

Res. https://doi.org/10.1007/s12011-021-02632-2.

42. Michalczyk K, Cymbaluk-Płoska A (2020) The role of zinc and copper in gynecological malignancies. Nutrients 12:3732. https://doi.org/10.3390/nu12123732.

43. Nouri M, Chalian H, Bahman A, Mollahajian H, Ahmadi-Faghih M, Fakheri H, Soroush A (2008) Nail molybdenum and zinc contents in populations with low and moderate incidence of esophageal cancer. Arch Iran Med 11(4):392-396.

44. Nurchi VM, Djordjevic AB, Crisponi G, Alexander J, Bjorklund G, Aaseth J (2020) Arsenic toxicity: molecular targets and therapeutic agents. Biomolecules 10, 235. https://doi.org/10.3390/biom10020235

45. Park Y, Leitzmann MF, Subar AF, Hollenbeck A, Schatzkin A (2009) Dairy food, calcium, and risk of cancer in the NIH-AARP diet and health study. Arch Intern Med 169:391-401. https://doi.org/10.1001/archinternmed.2008.578.

46. Prasad AS (2014) Zinc is an antioxidant and anti-inflammatory agent: its role in human health. Front Nutr 1:14 https://doi.org/10.3389/fnut.2014.00014

47. Pritchett NR, Burgert SL, Murphy GA, Brockman JD, White RE, Lando JL, Chepkwony R, Topazian MD, Abnet CC, Dawsey SM, Mwachiro MM (2017) Cross sectional study of serum selenium concentration and esophageal squamous dysplasia in western Kenya. BMC Cancer 17:835-

843. https://doi.org/10.1186/s12885-017-3837-9

48. Qayyum MA, Farooq Z, Yaseen M, Mahmood MHR, Irfan A, Zafar MN, Khawaja M, Naeem K, Kisa D, (2020) Statistical Assessment of Toxic and Essential Metals in the Serum of Female Patients with Lung Carcinoma from Pakistan. Bio Trace Elem Res 197:367-383. https://doi.org/10.1007/s12011-01901998-8

49. Rahman Z, Singh VP (2019) The relative impact of toxic heavy metals (THMs) (arsenic (As), cadmium (Cd), chromium (Cr)(VI), mercury (Hg), and lead $(\mathrm{Pb})$ ) on the total environment: an overview. Environ Monit Assess 191:419. https://doi.org/10.1007/s10661-019-7528-7

50. Ren Z, Rajani C, Jia W (2021) The distinctive serum metabolomes of gastric, esophageal and colorectal cancers. Cancers 13:720. https://doi.org/10.3390/cancers 13040720

51. Rice TW, Ishwaran H, Ferguson MK, Blackstone EH, Goldstraw P (2017) Cancer of the esophagus and esophagogastric junction: an eighth edition staging primer. J Thorac Oncol 12:36-42. https://doi.org/10.1016/j.jtho.2016.10.016

52. Shah SC, Dai Q, Zhu X, Peek RM, Jr. Roumie C, Shrubsole MJ (2020) Associations between calcium and magnesium intake and the risk of incident oesophageal cancer: an analysis of the nih-aarp diet and health study prospective cohort. Br J Cancer 122:1857-1864. https://doi.org/10.1038/s41416-

Page $15 / 23$ 
020-0818-6.

53. Sohrabi M, Nikkha M, Sohrabi M, Farimani AR, Shahi MM, Ziaie H, Solmaz S, Kohi Z, Delaram ZK, Salehpour D, Tameshkel FS, Hajibaba M, Zamani F, Ajdarkosh H, Sohrabi M, Gholami A (2021) Evaluating tissue levels of the eight trace elements and heavy metals among esophagus and gastric cancer patients: A comparison between cancerous and non-cancerous tissues. J Trace Elem Med Biol 68:126761. https://doi.org/10.1016/j.jtemb.2021.126761

54. StatSoft (1999) STATISTICA for Windows. Computer Program Manual, StatSoft, Tusla

55. Torti SV, Torti FM (2011) Ironing out cancer. Cancer Res 71(5) 1511-1514. https://doi.org/10.1158/0008-5472.CAN-10-3614

56. Turati F, Tramacere I, Vecchia CL, Negri E (2013) A meta-analysis of body mass index and esophageal and gastric cardia adenocarcinoma. Ann Oncol 24:609-617. https://doi.org/10.1093/annonc/mds244.

57. Wallace DR, Djordevic AB (2020) Heavy metal and pesticide exposure: a mixture of potential toxicity and carcinogenicity. Curr Opin Toxicol 19:7279. https://doi.org/10.1016/j.cotox.2020.01.001

58. Wang QL, Xie SH, Li WT, Lagergren J (2017) Smoking cessation and risk of esophageal cancer by histological type: systematic review and meta-analysis. J Natl Cancer Inst 1:109(12). https://doi.org/10.1093/jnci/djx115

59. Wang W, He SL, Yang YS, Chen LQ (2018) Strategies of nodal staging of the TNM system for esophageal cancer. Ann Transl Med 6(4):77. http://dx.doi.org/10.21037/atm.2017.12.17

60. Ward MH, Cross AJ, Abnet CC, Sinha R, Markin RS, Weisenburger DD (2012) Heme iron from meat and risk of adenocarcinoma of the esophagus and stomach. Eur J Cancer Prev 21:134-138. https://doi.org/10.1097/CEJ.0b013e32834c9b6c

61. Wei WQ, Abnet CC, Qiao YL, Dawsey SM, Dong ZW, Sun XD, Fan JH, Gunter EW, Taylor PR, Mark SD (2004) Prospective study of serum selenium concentrations and esophageal and gastric cardia cancer, heart disease, stroke, and total death. Am J Clin Nutr 79:8085. https://doi.org/10.1093/ajcn/79.1.80

62. Xie B, Lin J, Suia K, Huang Z, Chenb Z, Hang W (2019) Differential diagnosis of multielements in cancerous and non-cancerous esophageal tissues. Talanta 196:585-591. https://doi.org/10.1016/j.talanta.2018.12.061

63. Xu J, Wiseb JTF, Wangc L, Schumannd K, Zhangc Z, Shic X (2017) Dual roles of oxidative stress in metal carcinogenesis. J Environ Pathol Toxicol Oncol 36(4): 345-376. https://doi.org/10.1615/JEnvironPatholToxicolOncol. 2017025229.

64. Yang X, Chen X, Zhuang M, Yuan Z, Nie S, Lu M, Jin L, Ye W (2017) Smoking and alcohol drinking in relation to the risk of esophageal squamous cell carcinoma: A population-based case-control study in China. Sci Rep 7:17249. https://doi.org/10.1038/s41598-017-17617-2

65. Yang Y, Huang X, Zhou L, Deng T, Ning T, Liu R, Zhang L, Bai M, Zhang Z, Li H, Ba Y (2019) Clinical use of tumor biomarkers in prediction for prognosis and chemotherapeutic effect in esophageal squamous cell carcinoma, BMC Cancer 19:526. https://doi.org/10.1186/s12885-019-5755-5.

66. Yang YW , Dai CM, Chen XH, Feng JF (2021) The relationship between serum trace elements and oxidative stress of patients with different types of cancer. Oxid Med Cell Longev 2021:4846951. https://doi.org/10.1155/2021/4846951

\section{Tables}

\section{Table 1}

Optimum analytical conditions for the metal analyses along with their limits of detection/quantification and certified vs measured concentrations* $(\mu \mathrm{g} / \mathrm{g})$ of the metals in standard reference materials 
Bovine muscle powder, NIST-SRM 8414

\begin{tabular}{|c|c|c|c|c|c|c|c|c|c|}
\hline Metal & $\begin{array}{l}\text { Wavelength } \\
(\mathrm{nm})\end{array}$ & $\begin{array}{l}\text { HC lamp } \\
\text { current (mA) }\end{array}$ & $\begin{array}{l}\text { Slit } \\
\text { width } \\
\text { (nm) }\end{array}$ & $\begin{array}{l}\text { Fuel-gas flow } \\
\text { rate (L/min.) }\end{array}$ & $\begin{array}{l}\text { Limit of } \\
\text { detection } \\
\text { (mg/L) }\end{array}$ & $\begin{array}{l}\text { Limit of } \\
\text { Quantification } \\
\text { (mg/L) }\end{array}$ & $\begin{array}{l}\text { Certified } \\
\text { Level }\end{array}$ & $\begin{array}{l}\text { Measured } \\
\text { Level }\end{array}$ & $\begin{array}{l}\text { Recovery } \\
(\%)\end{array}$ \\
\hline $\mathrm{Fe}$ & 248.3 & 8 & 0.2 & 2 & 0.004 & 0.019 & 71.2 & 71.9 & 100.9 \\
\hline $\mathrm{Ca}$ & 422.7 & 6 & 0.5 & 2 & 0.003 & 0.015 & 145 & 148.0 & 102.0 \\
\hline $\mathrm{Na}$ & 589.0 & 6 & 0.5 & 1.6 & 0.003 & 0.006 & 2,100 & 2,010 & 96.2 \\
\hline $\mathrm{K}$ & 766.5 & 5 & 0.5 & 1.9 & 0.002 & 0.010 & 15,170 & 15,050 & 99.2 \\
\hline $\mathrm{Mg}$ & 285.2 & 4 & 0.5 & 1.6 & 0.001 & 0.003 & 960 & 964.1 & 100.4 \\
\hline $\mathrm{Zn}$ & 213.9 & 4 & 0.5 & 2 & 0.001 & 0.005 & 142 & 144.5 & 101.8 \\
\hline Co & 240.7 & 6 & 0.2 & 2.2 & 0.005 & 0.016 & 0.007 & 0.069 & 98.6 \\
\hline $\mathrm{Sr}$ & 460.7 & 4 & 0.5 & 1.6 & 0.005 & 0.016 & 0.052 & 0.050 & 96.2 \\
\hline $\mathrm{Pb}$ & 217.0 & 7 & 0.3 & 1.8 & 0.015 & 0.035 & 0.380 & 0.375 & 98.7 \\
\hline $\mathrm{Li}$ & 670.4 & 4 & 0.5 & 1.6 & 0.003 & 0.009 & - & - & - \\
\hline $\mathrm{Se}$ & 196.0 & 10 & 1 & 1.2 & 0.004 & 0.007 & 0.076 & 0.073 & 96.1 \\
\hline $\mathrm{Sb}$ & 217.6 & 10 & 0.2 & 2.5 & 0.002 & 0.015 & 0.01 & 0.01 & 100.1 \\
\hline $\mathrm{Cu}$ & 324.8 & 3 & 0.5 & 1.8 & 0.005 & 0.013 & 2.84 & 2.82 & 99.3 \\
\hline $\mathrm{Mn}$ & 279.5 & 5 & 0.4 & 1.9 & 0.002 & 0.011 & 0.370 & 0.371 & 100.73 \\
\hline $\mathrm{Ni}$ & 232.0 & 4 & 0.15 & 1.7 & 0.005 & 0.018 & 0.05 & 0.052 & 103 \\
\hline $\mathrm{Cr}$ & 357.9 & 5 & 0.5 & 2.6 & 0.005 & 0.017 & 0.071 & 0.068 & 97.1 \\
\hline $\mathrm{Ag}$ & 328.1 & 4 & 0.5 & 2.8 & 0.001 & 0.008 & - & - & - \\
\hline $\mathrm{Cd}$ & 228.8 & 4 & 0.3 & 1.8 & 0.003 & 0.012 & 0.013 & 0.012 & 97.8 \\
\hline As & 193.7 & 8 & 1 & 1.2 & 0.005 & 0.018 & 0.009 & 0.009 & 100.5 \\
\hline $\mathrm{Hg}$ & 253.7 & 5 & 0.5 & 1.2 & 0.010 & 0.025 & 0.005 & 0.005 & 97.8 \\
\hline
\end{tabular}

* Triplicate sub-samples

Table 2

Characteristics of the subjects 


\begin{tabular}{|c|c|c|}
\hline \multirow[t]{2}{*}{ Parameters } & \multicolumn{2}{|l|}{ Serum } \\
\hline & Esophagus Cancer Patients & Controls \\
\hline$N$ & 378 & 353 \\
\hline \multicolumn{3}{|l|}{ Age (years) } \\
\hline Range (Mean) & $39-66(52)$ & $41-68(49)$ \\
\hline \multicolumn{3}{|l|}{ Tobacco Status } \\
\hline No use & $155(41 \%)$ & $159(45 \%)$ \\
\hline Use & $223(59 \%)$ & $194(55 \%)$ \\
\hline \multicolumn{3}{|l|}{ Habitat } \\
\hline Urban & $181(48 \%)$ & $205(58 \%)$ \\
\hline Rural & $197(52 \%)$ & $148(42 \%)$ \\
\hline \multicolumn{3}{|l|}{ Diet } \\
\hline Vegetarian & $204(54 \%)$ & $180(51 \%)$ \\
\hline Non-vegetarian & $174(46 \%)$ & $173(49 \%)$ \\
\hline \multicolumn{3}{|l|}{ Sex } \\
\hline Males & $178(47 \%)$ & $169(48 \%)$ \\
\hline Females & $200(53 \%)$ & $184(52 \%)$ \\
\hline \multicolumn{3}{|l|}{ Types of Esophagus Cancer } \\
\hline Adenocarcinoma & $212(56 \%)$ & - \\
\hline Squamous cell carcinoma & $166(44 \%)$ & - \\
\hline \multicolumn{3}{|l|}{ Pathological Stages } \\
\hline Stage I & $76(20 \%)$ & - \\
\hline Stage II & $113(30 \%)$ & - \\
\hline Stage III & $106(28 \%)$ & - \\
\hline Stage IV & $83(22 \%)$ & - \\
\hline \multicolumn{3}{|c|}{ Body Mass Index (BMI) $\left(\mathrm{Kg} / \mathrm{m}^{2}\right)$} \\
\hline Range (mean) & $21.57-24.91(23.98)$ & $16.87-20.61(18.05)$ \\
\hline \multicolumn{3}{|l|}{ CEA (Nano gram per milliliter) } \\
\hline Range (mean) & $218.5-4359(861.7)$ & - \\
\hline
\end{tabular}

Table 3

Statistical distribution of the elemental levels $(\mu \mathrm{g} / \mathrm{g}$, wet weight) in the serum of esophagus cancer patients and controls 


\begin{tabular}{|c|c|c|c|c|c|c|c|c|c|c|c|c|c|c|c|}
\hline & Min & Max & Mean & Median & SD & SE & Skewness & Kurtosis & Min & Max & Mean & Median & SD & SE & Skewness \\
\hline $\mathrm{Ca}$ & 12.33 & 47.34 & 28.68 & 29.64 & 6.917 & 0.654 & -0.098 & -0.340 & 27.48 & 59.18 & 42.84 & 43.16 & 6.417 & 0.684 & -0.177 \\
\hline $\mathrm{Fe}$ & 39.28 & 69.90 & 59.98 & 61.50 & 6.744 & 0.637 & -1.107 & 0.853 & 70.51 & 99.52 & 91.22 & 92.28 & 5.181 & 0.552 & -0.933 \\
\hline $\mathrm{Zn}$ & 0.333 & 6.588 & 3.616 & 3.935 & 1.471 & 0.139 & -0.257 & -0.705 & 3.441 & 7.769 & 5.883 & 5.760 & 0.803 & 0.086 & -0.213 \\
\hline $\mathrm{Cu}$ & 0.025 & 1.821 & 0.933 & 0.969 & 0.508 & 0.048 & -0.215 & -1.048 & 0.034 & 0.965 & 0.603 & 0.669 & 0.249 & 0.027 & -1.115 \\
\hline $\mathrm{Ni}$ & 0.006 & 5.299 & 0.539 & 0.478 & 0.533 & 0.050 & 6.449 & 57.37 & 0.045 & 0.817 & 0.295 & 0.235 & 0.188 & 0.020 & 1.003 \\
\hline $\mathrm{Cr}$ & 0.004 & 2.101 & 0.444 & 0.373 & 0.324 & 0.031 & 1.410 & 4.558 & 0.024 & 0.392 & 0.254 & 0.254 & 0.075 & 0.008 & -1.132 \\
\hline $\mathrm{Cd}$ & 0.001 & 0.099 & 0.044 & 0.039 & 0.026 & 0.002 & 0.507 & -0.841 & 0.020 & 0.035 & 0.025 & 0.025 & 0.003 & 0.001 & 0.339 \\
\hline $\mathrm{Pb}$ & 0.023 & 1.968 & 1.217 & 1.231 & 0.402 & 0.038 & -0.582 & 0.565 & 0.003 & 0.995 & 0.515 & 0.526 & 0.249 & 0.027 & -0.178 \\
\hline As & 0.011 & 0.100 & 0.040 & 0.034 & 0.023 & 0.002 & 0.825 & -0.175 & 0.010 & 0.089 & 0.022 & 0.017 & 0.012 & 0.001 & 2.634 \\
\hline $\mathrm{Ag}$ & 0.105 & 0.987 & 0.325 & 0.263 & 0.200 & 0.019 & 1.459 & 1.595 & 0.011 & 0.874 & 0.275 & 0.308 & 0.152 & 0.016 & 0.456 \\
\hline $\mathrm{Sr}$ & 0.804 & 1.988 & 1.418 & 1.381 & 0.271 & 0.026 & 0.035 & -0.811 & 1.096 & 2.438 & 1.856 & 1.881 & 0.355 & 0.038 & -0.166 \\
\hline $\mathrm{Li}$ & 0.927 & 2.083 & 1.174 & 1.043 & 0.346 & 0.033 & 2.150 & 2.740 & 0.976 & 3.836 & 1.791 & 1.661 & 0.556 & 0.059 & 0.902 \\
\hline $\mathrm{Hg}$ & 0.010 & 0.099 & 0.034 & 0.027 & 0.023 & 0.002 & 1.529 & 1.259 & 0.011 & 0.12 & 0.046 & 0.042 & 0.026 & 0.003 & 0.773 \\
\hline $\mathrm{Se}$ & 0.322 & 1.895 & 1.027 & 1.057 & 0.397 & 0.038 & -0.015 & -1.071 & 1.064 & 3.921 & 1.979 & 1.619 & 0.952 & 0.101 & 1.294 \\
\hline $\mathrm{Na}$ & 204.8 & 354.8 & 244.7 & 240.5 & 24.83 & 2.346 & 0.986 & 2.132 & 104.4 & 277.1 & 220.8 & 228.7 & 38.18 & 4.070 & -0.564 \\
\hline K & 150.8 & 199.0 & 171.0 & 170.8 & 13.37 & 1.264 & 0.382 & -0.697 & 101.8 & 267.4 & 199.4 & 199.3 & 40.01 & 4.265 & -0.257 \\
\hline $\mathrm{Mg}$ & 10.18 & 23.62 & 15.17 & 14.58 & 3.036 & 0.287 & 0.514 & -0.456 & 6.240 & 27.17 & 18.07 & 17.90 & 3.446 & 0.367 & -0.267 \\
\hline $\mathrm{Sb}$ & 0.167 & 1.642 & 0.970 & 0.972 & 0.367 & 0.035 & -0.192 & -0.602 & 0.128 & 3.813 & 1.213 & 1.207 & 0.718 & 0.077 & 0.971 \\
\hline $\mathrm{Mn}$ & 0.050 & 1.962 & 0.819 & 0.777 & 0.519 & 0.049 & 0.211 & -0.991 & 0.049 & 1.882 & 1.339 & 1.529 & 0.500 & 0.053 & -1.231 \\
\hline Co & 1.212 & 2.987 & 2.407 & 2.396 & 0.315 & 0.030 & -1.047 & 3.164 & 2.525 & 3.956 & 3.408 & 3.338 & 0.268 & 0.029 & -0.021 \\
\hline
\end{tabular}

Table 4

Correlation coefficient $(r)^{*}$ matrix for the elements in the serum of esophagus cancer patients (below the diagonal) and controls (above the diagonal) 


\begin{tabular}{|c|c|c|c|c|c|c|c|c|c|c|c|c|c|c|c|c|c|c|}
\hline & $\mathrm{Ca}$ & $\mathrm{Fe}$ & $\mathrm{Zn}$ & $\mathrm{Cu}$ & $\mathrm{Ni}$ & $\mathrm{Cr}$ & $\mathrm{Cd}$ & $\mathrm{Pb}$ & As & $\mathrm{Ag}$ & $\mathrm{Sr}$ & $\mathrm{Li}$ & $\mathrm{Hg}$ & $\mathrm{Se}$ & $\mathrm{Na}$ & $\mathrm{K}$ & $\mathrm{Mg}$ & $\mathrm{Sb}$ \\
\hline $\mathrm{Ca}$ & 1 & -0.34 & 0.54 & 0.28 & 0.40 & -0.44 & 0.23 & -0.45 & -0.49 & 0.02 & 0.65 & 0.19 & 0.02 & 0.19 & 0.57 & -0.54 & 0.55 & 0.33 \\
\hline $\mathrm{Fe}$ & 0.11 & 1 & 0.04 & -0.55 & -0.52 & 0.50 & 0.37 & 0.68 & 0.55 & 0.06 & 0.42 & -0.19 & 0.33 & 0.53 & 0.21 & -0.27 & 0.22 & -0.2 \\
\hline$Z n$ & -0.16 & -0.02 & 1 & 0.28 & 0.28 & -0.11 & 0.44 & -0.08 & -0.09 & 0.51 & -0.01 & 0.04 & -0.11 & -0.23 & -0.04 & 0.05 & 0.14 & -0.50 \\
\hline $\mathrm{Cu}$ & 0.26 & -0.13 & 0.06 & 1 & 0.11 & -0.42 & 0.13 & -0.23 & -0.56 & -0.43 & -0.31 & -0.38 & 0.59 & -0.26 & -0.15 & -0.15 & -0.55 & 0.13 \\
\hline $\mathrm{Ni}$ & 0.23 & -0.52 & 0.61 & 0.67 & 1 & 0.05 & 0.41 & 0.67 & -0.02 & 0.27 & 0.04 & -0.53 & -0.12 & -0.02 & -0.15 & 0.09 & 0.23 & 0.33 \\
\hline $\mathrm{Cr}$ & -0.04 & -0.21 & 0.09 & 0.70 & -0.17 & 1 & 0.33 & 0.58 & 0.62 & 0.46 & 0.46 & -0.02 & -0.04 & -0.42 & -0.03 & -0.24 & 0.34 & 0.52 \\
\hline $\mathrm{Cd}$ & 0.60 & 0.65 & 0.54 & 0.1 & 0.36 & 0.73 & 1 & 0.01 & 0.64 & 0.43 & 0.61 & 0.04 & -0.09 & -0.41 & -0.32 & 0.02 & 0.01 & 0.28 \\
\hline $\mathrm{Pb}$ & 0.07 & 0.11 & 0.01 & 0.25 & 0.41 & 0.64 & 0.52 & 1 & 0.55 & -0.07 & 0.48 & -0.39 & 0.51 & -0.04 & 0.39 & -0.41 & 0.25 & -0.57 \\
\hline As & 0.43 & 0.41 & -0.15 & -0.56 & -0.31 & 0.65 & -0.08 & 0.35 & 1 & 0.37 & 0.75 & 0.14 & -0.09 & -0.54 & 0.04 & -0.12 & 0.36 & -0.31 \\
\hline $\mathrm{Ag}$ & -0.21 & 0.01 & 0.08 & 0.57 & 0.16 & -0.39 & 0.47 & -0.14 & -0.13 & 1 & 0.31 & 0.81 & -0.57 & 0.06 & -0.31 & 0.15 & 0.54 & 0.32 \\
\hline $\mathrm{Sr}$ & 0.57 & 0.06 & 0.36 & -0.02 & 0.04 & 0.03 & 0.22 & 0.12 & -0.03 & 0.45 & 1 & -0.07 & -0.16 & -0.49 & 0.02 & -0.23 & 0.32 & -0.42 \\
\hline $\mathrm{Li}$ & 0.31 & -0.18 & 0.02 & 0.08 & 0.59 & -0.24 & 0.47 & -0.15 & 0.07 & 0.71 & 0.09 & 1 & -0.24 & 0.43 & -0.22 & 0.37 & 0.11 & 09.3 \\
\hline $\mathrm{Hg}$ & 0.25 & 0.15 & 0.48 & 0.55 & 0.03 & -0.14 & 0.32 & -0.39 & 0.21 & 0.43 & 0.14 & 0.16 & 1 & -0.05 & -0.07 & -0.23 & -0.11 & -0.18 \\
\hline $\mathrm{Se}$ & 0.11 & -0.28 & 0.07 & 0.01 & 0.18 & -0.19 & 0.32 & -0.03 & -0.54 & 0.53 & 0.56 & 0.24 & 0.03 & 1 & 0.29 & 0.47 & 0.42 & 0.27 \\
\hline $\mathrm{Na}$ & -0.23 & -0.13 & 0.17 & 0.55 & 0.07 & -0.09 & 0.28 & -0.25 & -0.21 & 0.23 & 0.59 & 0.25 & 0.49 & 0.05 & 1 & -0.59 & -0.51 & -0.38 \\
\hline K & -0.24 & -0.03 & 0.25 & 0.08 & -0.09 & -0.19 & 0.23 & -0.06 & 0.54 & 0.59 & 0.19 & 0.17 & 0.56 & 0.4 & 0.52 & 1 & 0.04 & 0.19 \\
\hline $\mathrm{Mg}$ & -0.13 & -0.21 & 0.26 & -0.55 & 0.53 & 0.24 & 0.19 & 0.11 & -0.04 & 0.11 & 0.48 & 0.51 & -0.17 & -0.01 & -0.51 & 0.06 & 1 & 0.04 \\
\hline $\mathrm{Sb}$ & -0.07 & -0.24 & 0.19 & -0.30 & 0.43 & -0.13 & 0.22 & -0.57 & -0.34 & 0.59 & 0.48 & 0.33 & 0.09 & 0.06 & 0.39 & 0.33 & 0.18 & 1 \\
\hline $\mathrm{Mn}$ & 0.02 & -0.01 & -0.23 & 0.10 & 0.66 & 0.05 & -0.13 & -0.08 & 0.13 & -0.06 & -0.07 & -0.12 & 0.56 & -0.19 & -0.08 & -0.05 & -0.05 & 0.25 \\
\hline Co & -0.04 & 0.57 & 0.52 & 0.19 & -0.09 & 0.08 & -0.07 & 0.14 & 0.41 & -0.05 & 0.47 & 0.58 & -0.04 & -0.07 & -0.07 & 0.06 & 0.33 & 0.57 \\
\hline
\end{tabular}

\section{Table 5}

Principal component loadings of elements in the serum of esophagus cancer patients and controls 


\begin{tabular}{|c|c|c|c|c|c|c|c|c|c|c|c|c|c|c|}
\hline & \multicolumn{7}{|c|}{ Patients } & \multicolumn{7}{|c|}{ Controls } \\
\hline & PC1 & PC2 & PC3 & PC4 & PC5 & PC6 & PC7 & PC1 & PC2 & PC3 & PC4 & PC5 & PC6 & PC7 \\
\hline Eigen Value & 3.048 & 2.618 & 2.370 & 1.864 & 1.641 & 1.247 & 1.125 & 3.683 & 3.100 & 2.758 & 2.106 & 1.426 & 1.261 & 1.109 \\
\hline Total Variance (\%) & 20.24 & 13.09 & 11.85 & 9.318 & 8.206 & 6.825 & 6.129 & 21.08 & 15.42 & 10.51 & 9.634 & 7.155 & 6.132 & 4.307 \\
\hline $\begin{array}{l}\text { Cumulative } \\
\text { Variance (\%) }\end{array}$ & 20.24 & 33.33 & 45.18 & 54.50 & 62.70 & 69.53 & 75.65 & 21.08 & 36.49 & 47.00 & 56.64 & 63.79 & 69.93 & 74.23 \\
\hline $\mathrm{Ca}$ & -0.260 & 0.137 & -0.009 & 0.893 & 0.058 & -0.271 & -0.030 & -0.193 & 0.647 & 0.216 & -0.461 & 0.224 & -0.193 & 0.011 \\
\hline $\mathrm{Fe}$ & 0.890 & 0.364 & -0.008 & -0.093 & -0.013 & -0.187 & -0.141 & -0.077 & 0.359 & -0.075 & 0.065 & -0.234 & -0.144 & 0.045 \\
\hline $\mathrm{Zn}$ & -0.420 & 0.083 & 0.169 & -0.159 & -0.191 & -0.133 & 0.816 & 0.316 & 0.164 & 0.321 & 0.278 & -0.401 & 0.518 & 0.057 \\
\hline $\mathrm{Cu}$ & -0.099 & -0.024 & 0.485 & 0.653 & 0.058 & -0.233 & 0.225 & -0.298 & 0.368 & 0.379 & 0.379 & 0.513 & 0.121 & -0.128 \\
\hline $\mathrm{Ni}$ & 0.016 & -0.245 & -0.025 & 0.229 & -0.124 & -0.059 & 0.648 & 0.384 & -0.133 & 0.584 & -0.386 & 0.115 & 0.116 & 0.383 \\
\hline $\mathrm{Cr}$ & -0.058 & 0.621 & -0.02 & 0.095 & -0.089 & -0.016 & -0.069 & -0.492 & -0.065 & -0.043 & 0.314 & -0.355 & 0.078 & 0.572 \\
\hline $\mathrm{Cd}$ & -0.059 & -0.026 & 0.043 & 0.504 & -0.067 & -0.065 & 0.600 & 0.659 & 0.416 & 0.095 & 0.12 & 0.188 & -0.206 & 0.234 \\
\hline $\mathrm{Pb}$ & 0.574 & 0.441 & -0.286 & 0.522 & -0.027 & -0.824 & 0.097 & -0.407 & 0.508 & 0.104 & 0.235 & 0.027 & -0.137 & 0.414 \\
\hline As & -0.126 & 0.943 & 0.067 & 0.037 & -0.031 & -0.266 & 0.127 & -0.433 & 0.639 & -0.204 & 0.085 & 0.246 & -0.197 & -0.173 \\
\hline $\mathrm{Ag}$ & 0.358 & 0.850 & 0.212 & -0.206 & -0.019 & 0.221 & 0.051 & 0.804 & -0.044 & -0.255 & 0.192 & 0.12 & -0.082 & 0.198 \\
\hline $\mathrm{Sr}$ & -0.427 & 0.605 & 0.259 & -0.236 & -0.213 & -0.044 & -0.161 & 0.496 & 0.04 & 0.165 & 0.734 & -0.081 & -0.200 & 0.182 \\
\hline $\mathrm{Li}$ & -0.415 & 0.581 & -0.065 & -0.148 & -0.21 & 0.306 & -0.108 & 0.694 & 0.482 & 0.05 & -0.294 & 0.238 & 0.015 & -0.238 \\
\hline $\mathrm{Hg}$ & -0.198 & -0.355 & 0.387 & -0.133 & 0.491 & 0.06 & -0.043 & 0.542 & 0.388 & -0.357 & -0.031 & 0.095 & 0.338 & -0.116 \\
\hline $\mathrm{Se}$ & -0.035 & -0.033 & 0.021 & 0.057 & -0.008 & 0.917 & -0.364 & 0.319 & 0.411 & 0.572 & -0.315 & -0.086 & 0.111 & -0.092 \\
\hline $\mathrm{Na}$ & -0.063 & 0.082 & 0.848 & -0.079 & 0.101 & -0.211 & 0.104 & 0.451 & -0.258 & -0.026 & 0.941 & 0.274 & -0.227 & -0.485 \\
\hline K & 0.190 & -0.028 & 0.624 & -0.48 & -0.038 & 0.156 & 0.123 & 0.483 & 0.166 & -0.196 & 0.096 & 0.16 & 0.452 & -0.109 \\
\hline $\mathrm{Mg}$ & 0.133 & -0.108 & -0.058 & 0.872 & -0.062 & 0.180 & -0.106 & 0.286 & -0.095 & 0.313 & 0.512 & 0.065 & -0.431 & -0.09 \\
\hline $\mathrm{Sb}$ & -0.320 & 0.080 & -0.451 & 0.489 & 0.562 & -0.098 & 0.05 & 0.019 & -0.411 & 0.706 & -0.326 & 0.144 & -0.055 & -0.026 \\
\hline $\mathrm{Mn}$ & -0.150 & 0.265 & 0.713 & -0.150 & 0.256 & -0.064 & 0.145 & -0.225 & -0.295 & -0.191 & -0.016 & 0.654 & 0.208 & -0.011 \\
\hline Co & -0.070 & -0.263 & -0.125 & 0.686 & -0.163 & 0.025 & 0.453 & -0.272 & -0.277 & -0.09 & 0.113 & 0.688 & 0.178 & 0.324 \\
\hline
\end{tabular}

\section{Figures}



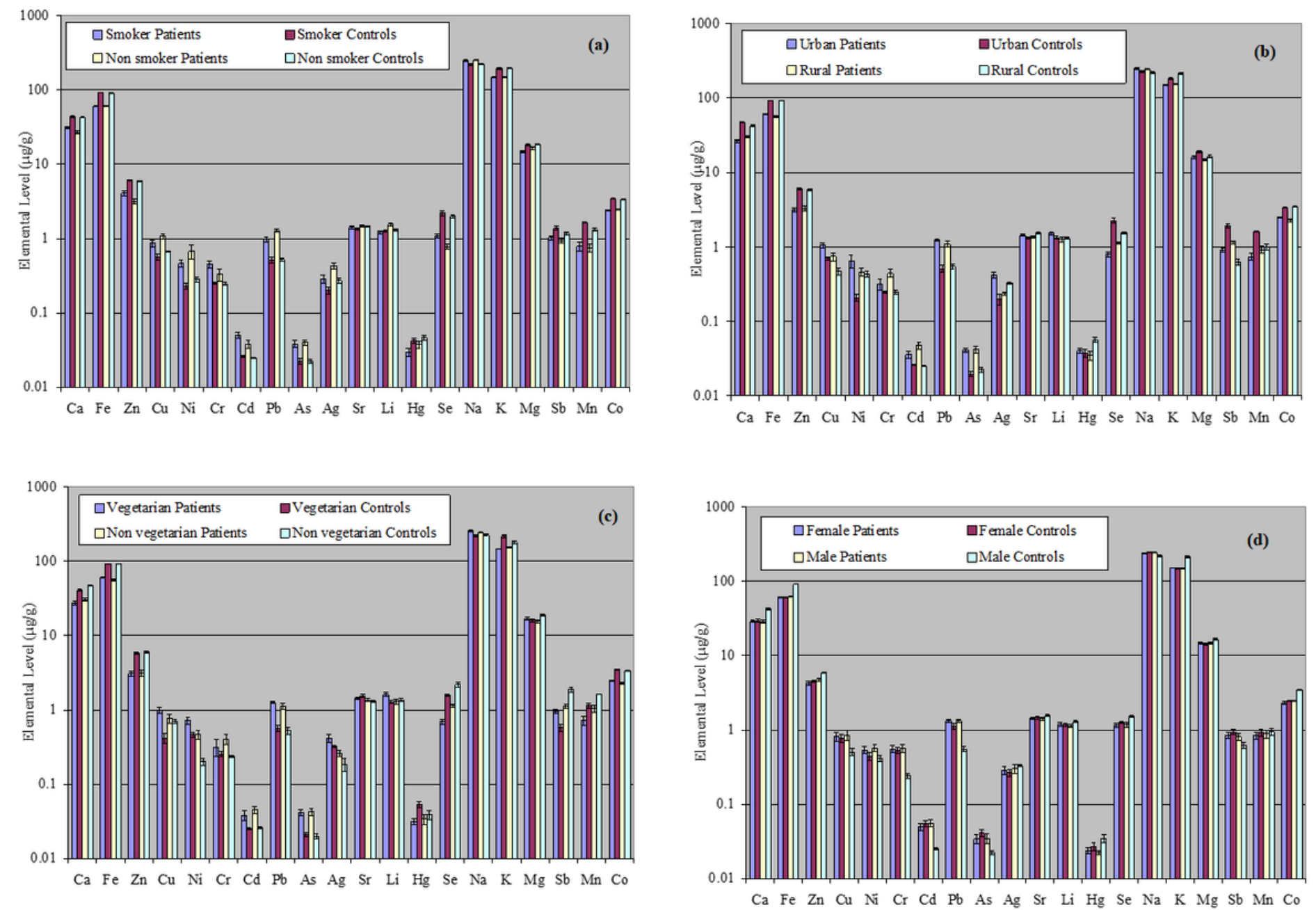

Figure 1

Comparison of the mean elemental levels $( \pm S E)$ in the serum of esophagus cancer patients and controls based on their (a) smoking habits, (b) abode, (c) dietary habits and $(\mathbf{d})$ gender
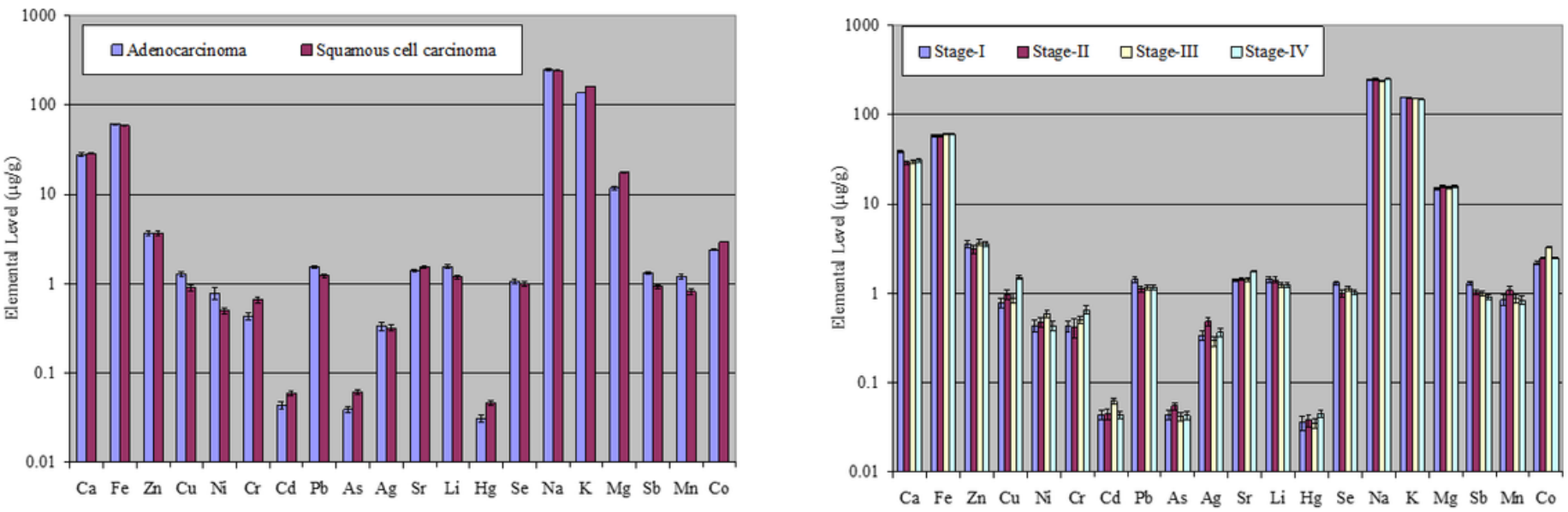

Figure 2

Comparison of the mean elemental levels $( \pm S E)$ in the serum of patients based on types and clinical stages of esophagus cancer 


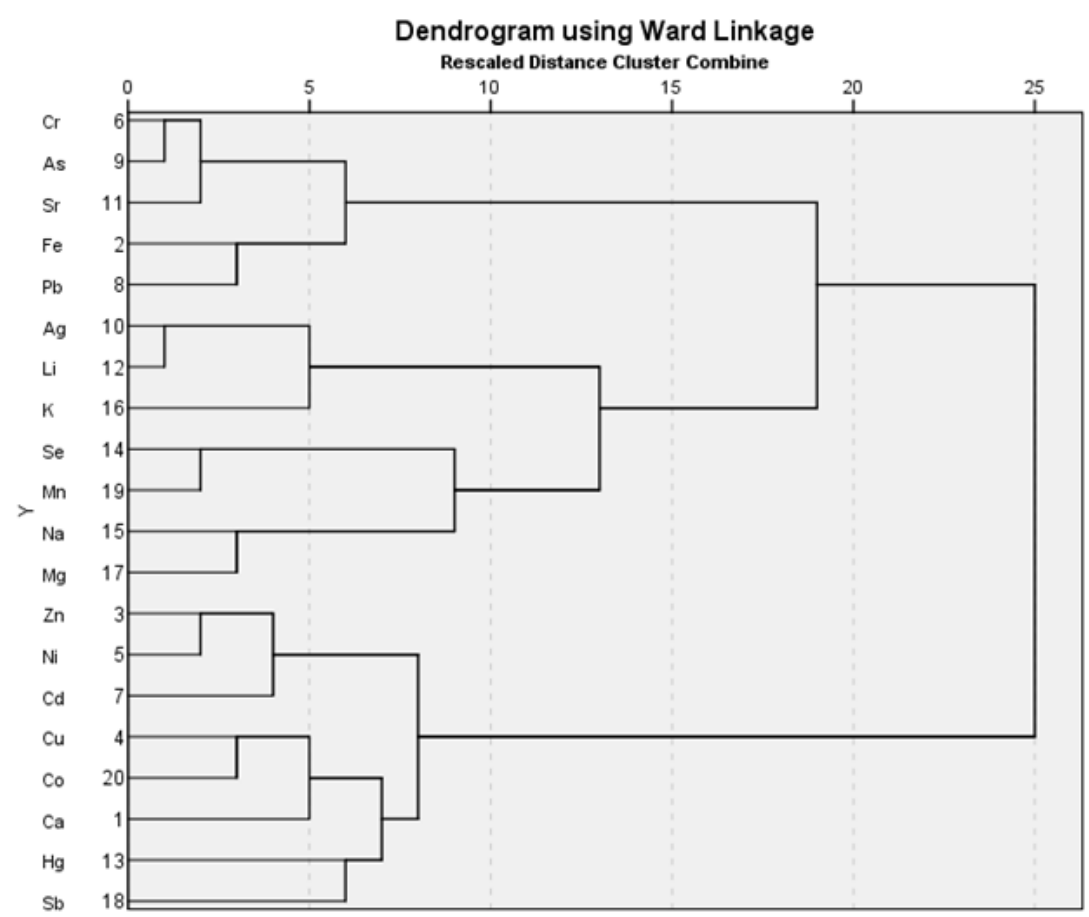

Figure 3

Cluster analysis as dendrogram of elements in the serum of esophagus cancer patients

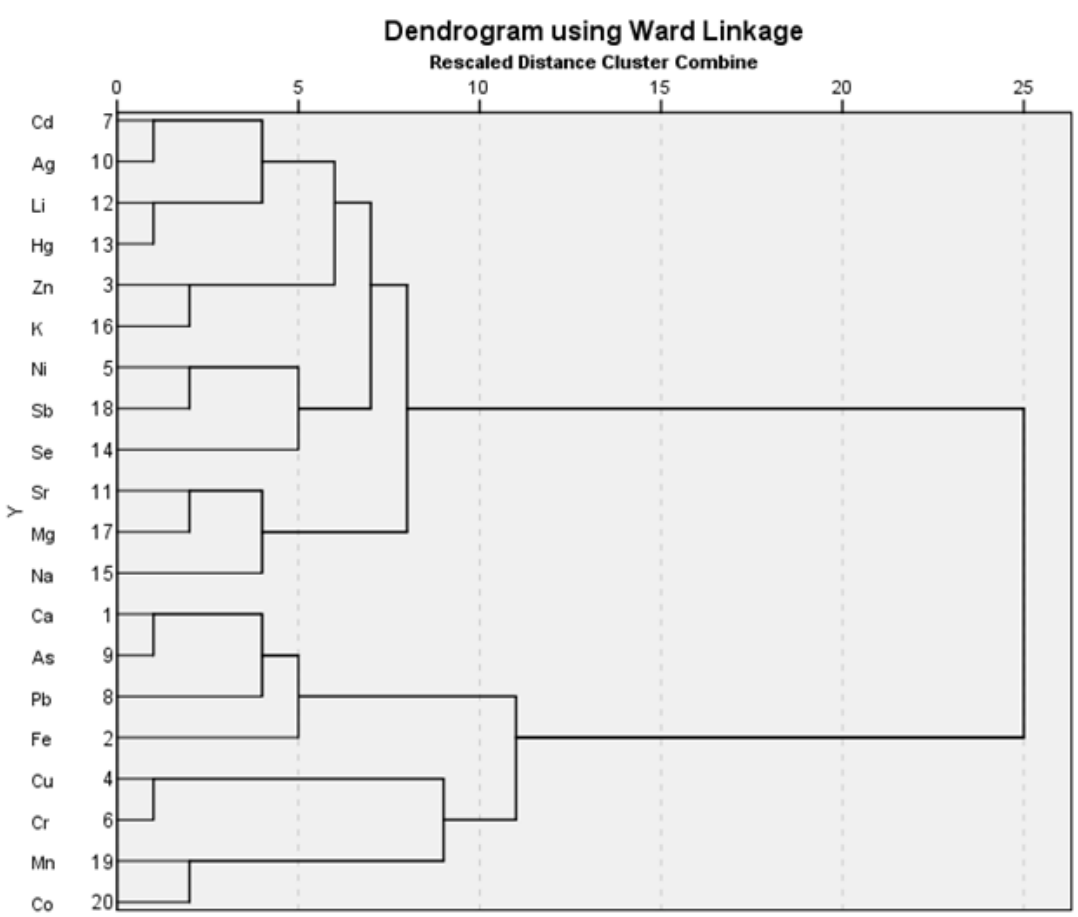

Figure 4

Cluster analysis as dendrogram of elements in the serum of controls 